\section{OPEN ACCESS}

Edited by:

Sunil Kumar Singh,

Physical Research Laboratory, India

Reviewed by:

Gregory De Souza,

ETH Zürich, Switzerland

Tarun K. Dalai,

Indian Institute of Science Education

and Research Kolkata, India

${ }^{*}$ Correspondence:

Ryan Cloete

15994619@sun.ac.za

Specialty section:

This article was submitted to Marine Biogeochemistry,

a section of the journal

Frontiers in Marine Science

Received: 20 January 2021 Accepted: 05 July 2021 Published: 26 July 2021

Citation:

Cloete R, Loock JC, van Horsten NR, Fietz S, Mtshali TN, Planquette $H$ and Roychoudhury AN (2021) Winter Biogeochemical Cycling of Dissolved and Particulate Cadmium in the Indian Sector of the Southern Ocean (GEOTRACES GIprO7

Transect). Front. Mar. Sci. 8:656321. doi: 10.3389/fmars.2021.656321

\title{
Winter Biogeochemical Cycling of Dissolved and Particulate Cadmium in the Indian Sector of the Southern Ocean (GEOTRACES GIpr07 Transect)
}

Ryan Cloete ${ }^{1 *}$, Jean C. Loock ${ }^{1}$, Natasha R. van Horsten $^{1,2,3}$, Susanne Fietz
,

${ }^{1}$ Centre for Trace Metal and Experimental Biogeochemistry (TracEx), Department of Earth Sciences, Stellenbosch University, Stellenbosch, South Africa, ${ }^{2}$ Southern Ocean Carbon \& Climate Observatory, Council for Scientific and Industrial Research (CSIR), Stellenbosch, South Africa, ${ }^{3}$ CNRS, IRD, Ifremer, LEMAR, Univ Brest, Plouzané, France, ${ }^{4}$ Oceans and Coast, Department of Environment, Forestry and Fisheries, Cape Town, South Africa

Winter distributions of dissolved cadmium ( $\mathrm{dCd}$ ) and particulate cadmium $(\mathrm{pCd})$ were measured for the first time in the Indian sector of the Southern Ocean thereby contributing a unique spatial and seasonal dataset. Seven depth profiles, between $41^{\circ} \mathrm{S}$ and $58^{\circ} \mathrm{S}$, were collected along the $30^{\circ} \mathrm{E}$ longitude during the 2017 austral winter to investigate the biogeochemical cycling of cadmium during a period characterized by contrasting upper water column dynamics compared to summer. Our results support an important role for biological uptake during winter months albeit weaker compared to summer. Distinct, biologically driven changes in cadmium cycling across the transect were observed. For example, surface ratios of pCd to phosphorus $(\mathrm{P} ; \mathrm{pCd}: \mathrm{P})$ increased from 0.37 to $1.07 \mathrm{mmol} \mathrm{mol}^{-1}$ between the subtropical zone (STZ) and the Antarctic zone (AAZ) reflecting increased Cd requirements for diatoms at higher latitudes which, in turn, was driven by a complex relationship between the availability of $\mathrm{dCd}$ and dissolved iron $(\mathrm{dFe})$, zinc $(\mathrm{dZn})$ and manganese $(\mathrm{dMn})$. Vertical profiles of $\mathrm{pCd}: \mathrm{P}$ displayed nearsurface maxima consistent with (1) P occurring in two phases with different labilities and the lability of $\mathrm{Cd}$ being somewhere in-between and (2) increasing dCd to phosphate $\left(\mathrm{PO}_{4} ; \mathrm{dCd}: \mathrm{PO}_{4}\right)$ ratios with depth at each station. North of the Antarctic Polar Front (APF), a secondary, deeper pCd:P maximum may reflect an advective signal associated with northward subducting Antarctic Intermediate Water (AAIW). The strong southward increase in surface $\mathrm{dCd}$ and $\mathrm{dCd}: \mathrm{PO}_{4}$, from approximately $10-700 \mathrm{pmol} \mathrm{kg}{ }^{-1}$ and 40-400 $\mu \mathrm{mol} \mathrm{mol}{ }^{-1}$, respectively, reflected the net effect of preferential uptake and regeneration of diatoms with high $\mathrm{Cd}$ content and the upwelling of $\mathrm{Cd}$ enriched water masses in the $A A Z$. Furthermore, distinct dCd versus $\mathrm{PO}_{4}$ relationships were observed in each of the intermediate and deep water masses suggesting that $\mathrm{dCd}$ and $\mathrm{PO}_{4}$ distributions at depth are largely the result of physical water mass mixing.

Keywords: trace metal, phytoplankton, GEOTRACES, Southern Ocean, dissolved cadmium, particulate cadmium, diatoms, winter 


\section{INTRODUCTION}

It is well established that numerous trace metals are required nutrients for phytoplankton and that trace metal availability in the world's oceans can influence phytoplankton growth and community structure (Twining and Baines, 2013) with potential consequences for the global carbon cycle. Data pertaining to the trace metal cadmium $(\mathrm{Cd})$ are scarce, particularly in the Southern Ocean (Schlitzer et al., 2018), however, it has allowed for a basic model of Cd cycling to be developed. The dominant external sources of $\mathrm{Cd}$ to the surface ocean are riverine discharge (Lambelet et al., 2013), natural and anthropogenic derived atmospheric deposition (Duce et al., 1991) and seasonal ice melt in the polar oceans (Hölemann et al., 1999). The internal cycling of Cd in the Southern Ocean is further controlled by complexation with natural organic ligands in surface waters (Ellwood, 2004), year-round mixing between water masses with different preformed $\mathrm{Cd}$ concentrations and upwelling at higher latitudes (Abouchami et al., 2014; Sieber et al., 2019). Additionally, deep winter mixing (or entrainment) is a seasonally constrained physical supply mechanism whereby deeper mixing in winter compared to summer allows access to nutrient rich subsurface water masses found below the summer stratified layer (Ellwood, 2008; Tagliabue et al., 2014).

In addition to its sources, Cd cycling can be extended to differentiate between various source pools of trace metals. The dissolved $\mathrm{Cd}$ pool $(<0.2 \mu \mathrm{m}$ pore size filtered seawater), denoted as "d," e.g., dCd hereafter, is recognized as the nutrient reservoir available for phytoplankton uptake. The particulate Cd pool ( $>0.45 \mu \mathrm{m}$ pore size filter), denoted as "p," e.g., pCd hereafter, is not considered bioavailable to phytoplankton yet contributes significantly to the total $\mathrm{Cd}$ inventory in the ocean (Turekian, 1977; Lam and Marchal, 2015). A host of biophysicochemical processes control the cycling and exchange between dissolved and particulate cadmium in the ocean. In the surface ocean, uptake of $\mathrm{dCd}$ by phytoplankton and recycling upon cell death are the primary processes that facilitate the exchange between inorganic dCd and organic pCd. Subsequent processes, such as zooplankton grazing, result in the formation of larger particles which either sink and contribute to the vertical export of $\mathrm{pCd}$, or disaggregate and return $\mathrm{Cd}$ to the dissolved pool through remineralisation, desorption and dissolution, either in the euphotic or mesopelagic zone (Lam and Marchal, 2015). Scavenging (or adsorption) of dCd onto organic or hydrothermally sourced particles may enhance export of Cd through formation of more rapidly sinking particulate phases (Conway and John, 2015). Similarly, precipitation of solid Cd sulfides in euxinic microenvironments (e.g., within particles) increases pCd export in localized regions (Janssen et al., 2014). As a result of the interplay of all these processes, increases in water column dCd typically co-occur with decreases in pCd and vice versa (Quay et al., 2015). However, dissolved and particulate phases are not exact mirror images of each other considering that water column processes lead to differences in their respective oceanic residence times, e.g., years to thousands of years for dissolved phases and days to months for particulate phases (Lam and Marchal, 2015).
The first reliable open ocean dCd measurements (Boyle et al., 1976; Bruland et al., 1978) were well correlated with the major nutrient phosphate $\left(\mathrm{PO}_{4}\right)$ and showed a surface depletion $\left(<2 \mathrm{pmol} \mathrm{kg}{ }^{-1}\right)$ relative to the deeper waters $\left(>1,000\right.$ pmol $\left.\mathrm{kg}^{-1}\right)$, as is typical of nutrient-type behavior. Indeed, a diatom specific carbonic anhydrase (CA) enzyme containing Cd (CDCA) has been identified, supporting $\mathrm{Cd}$ uptake (Lane and Morel, 2000; Lane et al., 2005). Furthermore, $\mathrm{Cd}$ may stimulate the growth of zinc ( $\mathrm{Zn}$ )-limited diatoms through a substitutive mechanism (Price and Morel, 1990). The substitution of $\mathrm{Cd}$ for $\mathrm{Zn}$ under low $\mathrm{Zn}$ conditions has also been observed in other phytoplankton groups which do not contain the CDCA enzyme, notably coccolithophores and chlorophytes (Lee and Morel, 1995; Xu et al., 2007). These findings provide a potential mechanism responsible for the observed coupling of $\mathrm{Cd}$ and $\mathrm{PO}_{4}$. However, there are divergences in the global oceanic $\mathrm{Cd}-\mathrm{PO}_{4}$ relationship, with a pronounced break ('kink') in the slope at $\mathrm{PO}_{4} \sim 1.3 \mu \mathrm{mol} \mathrm{kg}-1$, indicating a net preferential removal of $\mathrm{Cd}$ from surface waters (Elderfield and Rickaby, 2000). Many studies have investigated the assimilation of $\mathrm{PO}_{4}$ and $\mathrm{Cd}$ in phytoplankton and revealed different factors influencing the uptake of $\mathrm{Cd}$ relative to $\mathrm{PO}_{4}$. For example, a diatom dominated phytoplankton assemblage showed decreases in cellular $\mathrm{Cd}$ in response to the addition of the key micronutrient iron $(\mathrm{Fe})$ suggesting $\mathrm{Cd}$ uptake is directly linked to Fe availability (Cullen et al., 2003). Subsequent experiments have shown that increased cellular $\mathrm{Cd}$ in response to low $\mathrm{Fe}$ availability may follow one of two potential mechanisms. First, biodilution occurs in Fe-limited phytoplankton where reduced growth rates result in slower accumulation of $\mathrm{P}$ while $\mathrm{Cd}$ uptake remains relatively constant ultimately causing elevated $\mathrm{pCd}: \mathrm{P}$ signatures (Cullen, 2006). Second, increased dCd uptake can occur through non-specific Fe transporters when phytoplankton are exposed to low levels of Fe (Lane et al., 2008, 2009). In addition to Fe, increased cellular Cd is also inversely related to the availability of other essential micronutrients such as $\mathrm{Zn}$ and manganese (Mn; Sunda and Huntsman, 2000) and may be further modulated by dissolved carbon dioxide $\left(\mathrm{CO}_{2}\right)$ concentrations in surface waters (Cullen et al., 1999; Cullen and Sherrell, 2005). Here, and in addition to the previously mentioned biological uses, Cd may be taken up passively with these divalent metals and bound within the cell to prevent toxicity (Horner et al., 2013). In sum, the role of $\mathrm{Cd}$ as a micronutrient is dependent on a number of oceanographic properties including the availability of other bio-essential trace metal concentrations, notably Fe, Zn, and Mn.

Understanding the biogeochemical cycling of $\mathrm{Cd}$ in the Southern Ocean is particularly important given that water masses formed in this region are the primary communication channels to the low latitude oceans (Broecker, 1991). The far reaching influence of the Southern Ocean has been shown in terms of macronutrient distributions (Frew and Hunter, 1992; Sarmiento et al., 2004) as well as for Cd (Baars et al., 2014; Xie et al., 2015; Middag et al., 2018; Sieber et al., 2019) highlighting the combination of biological uptake in the surface Southern Ocean, lateral transport and mixing between water masses with different preformed nutrient signatures. While significant strides have been made in identifying and understanding processes 
controlling oceanic Cd distributions, spatial and seasonal gaps in the global database still exist. For example, the Indian sector of the Southern Ocean is particularly data scarce (Janssen et al., 2020). Additionally, most observations to date represent spring/summer seasons with few winter $\mathrm{Cd}$ measurements available (Ellwood, 2008). We therefore have little understanding of Cd cycling over seasonal cycles and of the conditions that characterize the Southern Ocean during winter, a period which may be critical in supplying $\mathrm{Cd}$ and other nutrients (e.g., $\mathrm{Fe}$ ) to sustain phytoplankton growth over the subsequent spring and summer seasons (Tagliabue et al., 2014). Under the GEOTRACES framework, this study aims to improve our understanding of $\mathrm{Cd}$ biogeochemical cycling in the ocean by contributing the first winter dissolved and particulate measurements of $\mathrm{Cd}$ from the western Indian sector (WOCE meridional section IO6S; GEOTRACES section GIpr07) of the Southern Ocean.

\section{METHODOLOGY}

\section{Sample Collection}

Seawater samples were collected on-board the South African (SA) Agulhas II polar research vessel during the 2017 Winter Cruise (WC-17; 28/06/2017-13/07/2017). The cruise transect followed the World Ocean Circulation Experiment (WOCE) I06 transect along the $30^{\circ} \mathrm{E}$ meridian in the Indian sector of the Southern Ocean (Figure 1A). Seven stations, consisting of four deep and three shallow, were sampled between $41^{\circ} 00^{\prime} \mathrm{S}$ and $58^{\circ} 30^{\prime} \mathrm{S}$ allowing observations over important frontal systems and in different water masses. "Deep" stations were sampled from near the surface $(25 \mathrm{~m})$ to near sea-floor $(<4,500 \mathrm{~m})$ while "shallow" stations were sampled between near surface and 1,500 $\mathrm{m}$ depth.

Seawater samples were collected following a strict 'trace metal clean' GEOTRACES protocol (Cutter et al., 2017). A vertical profile sampling method was employed, using 24 trace clean, internally Teflon-coated polyvinyl chloride (PVC) 12 L GO-FLO sampling bottles mounted on an epoxy-coated aluminum frame conductivity-temperature-depth (CTD) rosette. The rosette also housed sensors used to obtain vertical profiles of temperature, salinity, fluorescence and photosynthetically active radiation (PAR). A Kevlar hydrowire with internal signal cables allowed for the transfer of data between the CTD and the on-board control room. The GO-FLO bottles were triggered at predetermined depths during the up cast. Directly upon recovery of the rosette, the GO-FLO bottles were covered in a PVC plastic wrap in addition to their ends being covered in plastic (PVC) shower caps, and were transported into a class 100 clean container lab for sub-sampling. Samples for dissolved trace metal determination

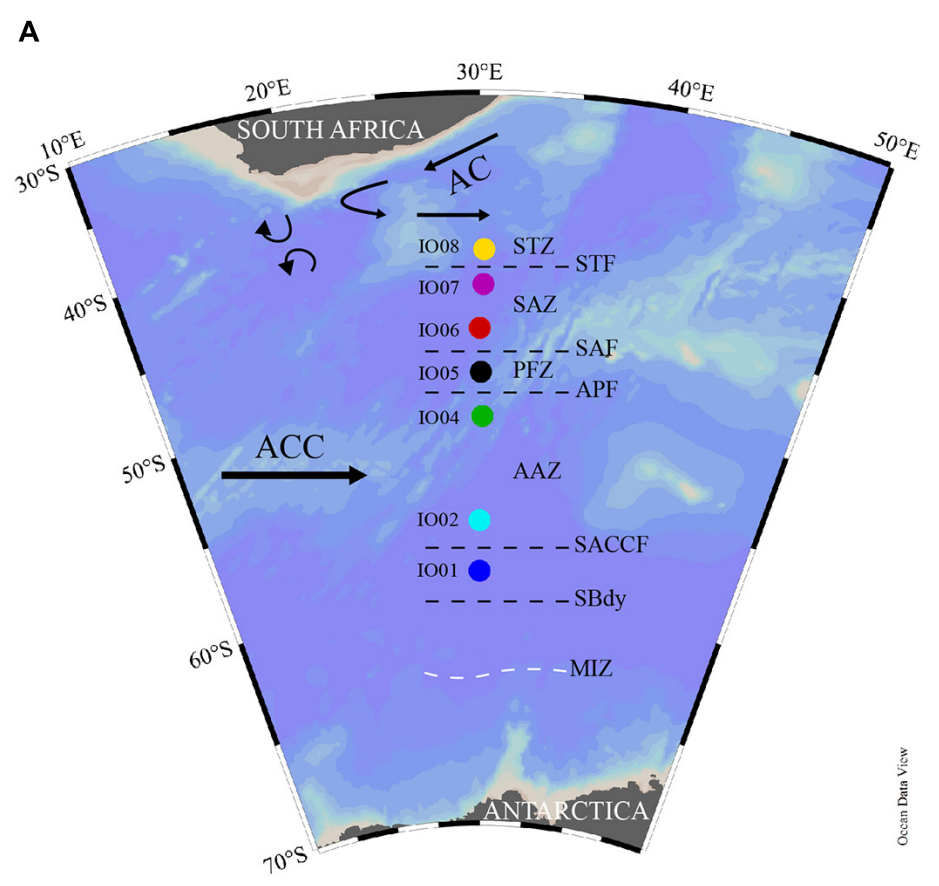

B

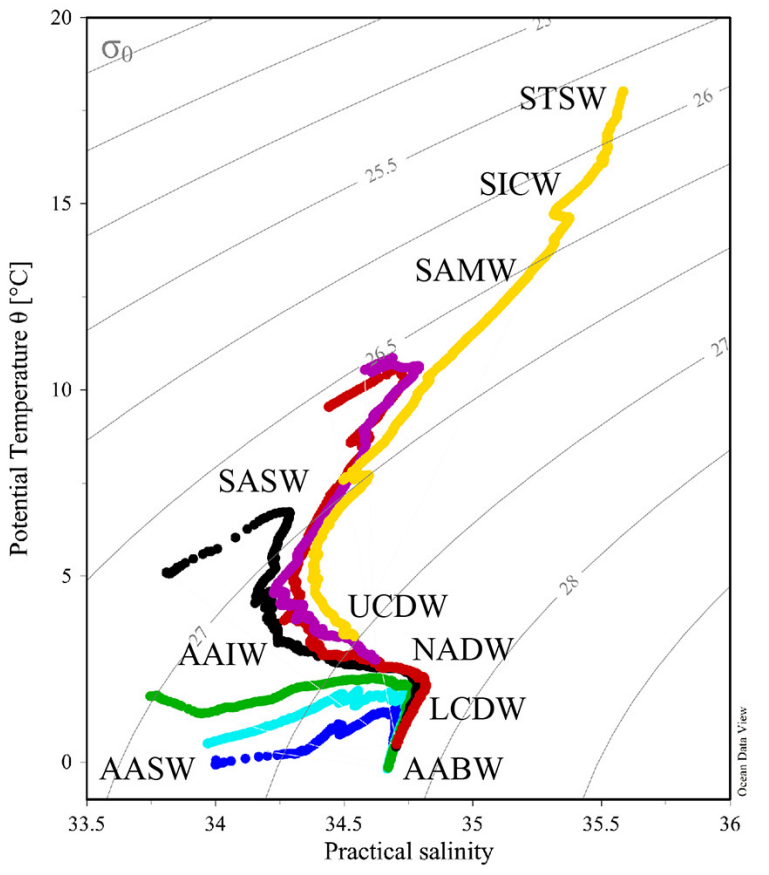

FIGURE 1 | (A) Sample station locations during the 2017 Winter Cruise along the GEOTRACES Glpr07 transect, equivalent to World Ocean Circulation Experiment (WOCE) 106 transect. Positions of the frontal systems intersected, and corresponding oceanic zones, are shown as well as the main surface currents. Acronyms in alphabetical order are as follows; AAZ, Antarctic Zone; AC, Agulhas Current; ACC, Antarctic Circumpolar Current; APF, Antarctic Polar Front; MIZ, Marginal Ice Zone; PFZ, Polar Frontal Zone; SACCF, Southern Antarctic Circumpolar Current Front; SAF, Subantarctic Front SAZ: Subantarctic Zone; SBdy, Southern Boundary; STF, Subtropical Front; STZ, Subtropical Zone. (B) Scatter plot of potential temperature $\left({ }^{\circ} \mathrm{C}\right)$ against practical salinity used to characterize the water mass regime. Acronyms in alphabetical order are as follows; AABW, Antarctic Bottom Water; AAIW, Antarctic Intermediate Water; AASW, Antarctic Surface Water; LCDW, Lower Circumpolar Deep Water; NADW, North Atlantic Deep Water; SAMW, Subantarctic Mode Water; SASW, Subantarctic Surface Water; SICW, South Indian Central Water; STSW, Subtropical Surface Water; UCDW, Upper Circumpolar Deep Water. Figures constructed using Ocean Data View (ODV; Schlitzer, 2020). 
were collected into $125 \mathrm{~mL}$ acid-cleaned low density polyethylene (LDPE) bottles after online filtration through $0.2 \mu \mathrm{m}$ pore size capsule filters (Sartobran) and under slight $\mathrm{N}_{2}$ gas (0.5 bar, 99.9999\% $\mathrm{N}_{2}$, BIP technology) overpressure. Samples were acidified ( $\mathrm{pH} \sim 1.7$ ) under laminar flow using hydrochloric acid (30\% Ultrapur ${ }^{\circledR} \mathrm{HCl}$, Merck) and stored at room temperature for later analysis. Thereafter, previously cleaned filters $(25 \mathrm{~mm}$ diameter, Supor, $0.45 \mu \mathrm{m}$ pore size) were mounted on acidwashed Swinnex (Millipore) filter holders which were then attached to the GO-FLO spigots and used for filtration (5$10 \mathrm{~L})$ of samples for particulate trace metal determination (Planquette and Sherrell, 2012). After filtration, filter holders were removed and disassembled before the sampled filter was transferred to an acid-washed polystyrene Petri-dish using clean plastic forceps. Sampled filters were subsequently frozen at $-20^{\circ} \mathrm{C}$ for transport back to the shore lab. All handling of filters, filter holders and samples was done under a class 100 laminar flow hood.

\section{Dissolved Cadmium (dCd) Determination seaFAST and ICP-MS}

Samples were analyzed by Inductively Coupled Plasma Mass Spectrometry (ICP-MS, Agilent 7900), after offline preconcentration by Solid Phase Extraction (SPE) on a seaFAST SC-4 DX module (Cloete et al., 2019). Briefly, $10 \mathrm{~mL}$ of seawater was taken up by the seaFAST (Elemental Scientific Inc.) module, buffered with an ammonium acetate buffer to a $\mathrm{pH}$ of $6.0 \pm 0.2$, and loaded onto a high affinity metal chelating resin column (Nobias PA1). Here the metal ions including $\mathrm{Cd}$ were bound to the resin and separated from the seawater matrix elements, e.g., $\mathrm{Na}, \mathrm{Mg}$, and $\mathrm{Cl}$ which passed through the column. The metal ions were subsequently eluted (in a $2 \% \mathrm{HNO}_{3}$ solution; Ultrapur $^{\circledR}$, Merck) from the resin column in low volumes $(250 \mu \mathrm{L})$ resulting in a preconcentration factor of 40 . On the ICP-MS, samples were introduced using a low self-aspirating perfluoroalkoxy (PFA) nebulizer with a flow rate of $0.2 \mathrm{~mL}$ $\min ^{-1}$. Cd was measured using the instruments Octopole Reaction System (ORS) in helium (He) collision mode to reduce plasma and matrix based interferences, e.g., molybdenum oxide $\left(\mathrm{MoO}^{+}\right)$interference on $\mathrm{Cd}$, although the molybdenum concentration was extensively reduced by the seaFAST matrix removal system. In order to quantify any remaining $\mathrm{MoO}^{+}$ interference on Cd, a Cd-free Mo standard at typical seawater concentrations (10-100 $\mathrm{nmol} \mathrm{\textrm {kg } ^ { - 1 }}$ ) was analyzed. Instrument parameters were optimized to reduce the interference to a

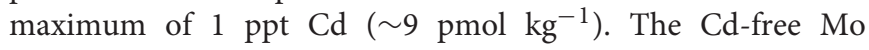
standard was included throughout the analysis to monitor $\mathrm{MoO}^{+}$production and correct the Cd results. Online internal standard addition for drift correction was not possible using the self-aspirating nebulizer. Instead, instrument drift was monitored by running a multi-element calibration standard (MES; supplied by Inorganic Ventures) every six samples. Where drift exceeded $5 \%$ relative to the starting concentration of the MES for a specific element, a drift correction was applied using the formula: $2^{*}$ Conc $_{\text {MES_start }} /\left(\text { Conc }_{\text {MES_a }}+\text { Conc }_{\text {MES_b }}\right)^{*}$ Conc $_{\text {Sample }}$, where $a$ and $b$ are the MES before and after each set of six samples.

\section{Accuracy and Precision}

The accuracy of the method was verified by the analysis of numerous community reference seawater samples for dCd (Table 1). For the GEOTRACES SAFe D2, GSC and GSP reference seawater, our dCd concentrations were within analytical uncertainty estimates of consensus values confirming the method's accuracy over a wide concentration range. Our mean dCd value from the analysis of the NASS-7 certified reference material (CRM) was within analytical uncertainty of the certified dCd value. To monitor ICP-MS precision, the Winter Indian Southern Ocean Seawater (WISOS) internal control seawater was placed in the analysis sequence and results compared against each other and the calibrated mean (Table 1). The WISOS internal control was collected in bulk $(20 \mathrm{~L})$ from surface water at $55^{\circ} \mathrm{S} ; 28^{\circ} \mathrm{E}$ during the 2017 Winter Cruise after filtration through a $0.2 \mu \mathrm{m}$ filter into an acid cleaned LDPE container. Sub-samples $(1 \mathrm{~L})$ of the bulk seawater were then acidified $(\mathrm{pH}=1.7)$ using hydrochloric acid (30\% $\mathrm{HCl}$, Ultrapur ${ }^{\circledR}$, Merck). The calibrated dCd mean $\left(888 \pm 21 \mathrm{pmol} \mathrm{kg}^{-1}\right)$ concentration was established by replicate analysis $(n=10)$ of the WISOS internal control seawater in conjunction with the SAFe and NASS-7 reference materials. Results from the analysis of the in-run WISOS control sample were $899 \pm 27 \mathrm{pmol} \mathrm{kg}^{-1}(n>30)$ confirming the method's precision over multiple analytical sessions.

TABLE 1 | Results for dCd from the ICP-MS analysis of GEOTRACES SAFE D2, GSC, and GSP seawater reference materials (https://www.geotraces.org/standards-and-reference-materials/), NASS-7 certified seawater reference material and our own WISOS internal reference seawater are compared with respective consensus values.

\begin{tabular}{|c|c|}
\hline & dCd \\
\hline & pmol kg ${ }^{-1}$ \\
\hline \multicolumn{2}{|l|}{ SAFe D2 } \\
\hline Consensus & $986 \pm 23$ \\
\hline Measured $(n=4)$ & $982 \pm 10$ \\
\hline \multicolumn{2}{|l|}{ GSC } \\
\hline Consensus & $355 \pm 21$ \\
\hline Measured $(n=5)$ & $345 \pm 21$ \\
\hline \multicolumn{2}{|l|}{ GSP } \\
\hline Consensus & $1.95 \pm 1,95$ \\
\hline Measured $(n=5)$ & $4.07 \pm 0.48$ \\
\hline \multicolumn{2}{|l|}{ NASS-7 } \\
\hline Certified & $141.50 \pm 14.40$ \\
\hline Measured $(n=5)$ & $132.69 \pm 3.08$ \\
\hline \multicolumn{2}{|l|}{ WISOS reference material } \\
\hline TracEx calibration $(n=10)$ & $888.02 \pm 21.22$ \\
\hline Measured $(n=5)$ & $899.41 \pm 27.55$ \\
\hline \multicolumn{2}{|l|}{ Blanks } \\
\hline Method $(n=5)$ & $1.22 \pm 0.30$ \\
\hline Limit of detection $(n=5)$ & 0.89 \\
\hline
\end{tabular}

Consensus values for SAFe D2 as of 2013 and GSC and GSP as of 2019. Calibrated mean values for WISOS calculated by repeat analysis $(n>10)$ of a large volume surface seawater sample collected from $55^{\circ} \mathrm{S} ; 28^{\circ} \mathrm{E}$. Instrument and method blanks as well as ICP-MS limit of detection are also shown. 


\section{Blanks and Limits of Detection}

The method blank (seaFAST and ICP-MS) was determined by preconcentrating and analyzing a solution of $2 \% \mathrm{HNO}_{3}$ (Ultrapur ${ }^{\circledR}$, Merck) in ultrapure deionized water (the same composition as the eluent used in sample pre-concentration). The method blank was subjected to the same pre-concentration procedure as the seawater samples. The mean method blank was $1.22 \pm 0.30 \mathrm{pmol} \mathrm{kg}^{-1}(n=5)$. The limit of detection (LOD) of the instrument, calculated as 3 times the standard deviation of the preconcentrated blanks, was $0.89 \mathrm{pmol} \mathrm{kg}^{-1}(n=5)$.

\section{Data Processing}

Samples for dCd were analyzed in duplicate. The final values represent the mean of duplicate measurements. In the two cases where the percentage relative standard deviation (\%RSD) between the duplicate measurements was $>10 \%$, one of the values was deemed a suspected outlier and not used further. This was determined by curve fitting the data points based on the values above (shallower depth) and below (deeper depth) the suspect value as well as by comparison with other parameters (salinity, temperature, and nutrients) measured from the same GO-FLO bottle.

\section{Phosphate $\left(\mathrm{PO}_{4}\right)$ Determination}

Seawater samples for macronutrient analysis were collected from GO-FLO bottles, filtered immediately after collection using a $0.2 \mu \mathrm{m}$ pore size syringe filter (Anotop) into $50 \mathrm{~mL}$ Falcon ${ }^{\circledR}$ tubes and frozen at $-20^{\circ} \mathrm{C}$. Post cruise, $\mathrm{PO}_{4}$ was determined manually by colorimetric method (Grasshoff, 1983) at the Marine Biogeochemistry Laboratory at the University of Cape Town (MBL-UCT; Weir et al., 2020). The analytical error of the $\mathrm{PO}_{4}$ measurements was $\pm 0.06 \mu \mathrm{mol} \mathrm{kg}^{-1}$ (Weir et al., 2020).

\section{Particulate Cadmium (pCd) and Phosphorus (P) Determination}

The pCd and P samples were processed and analyzed 6 months after sample collection according to established methods (Planquette and Sherrell, 2012). Filters containing the samples were acid reflux digested at $130^{\circ} \mathrm{C}$ in acid-cleaned Savillex screwcap vial. Archive solutions were stored in $3 \mathrm{~mL}$ of $0.12 \mathrm{M}$ $\mathrm{HNO}_{3}$ (Ultrapur ${ }^{\circledR}$, Merck), of which $250 \mu \mathrm{L}$ was diluted up to $2 \mathrm{~mL}$ for analysis by sector field inductively coupled plasma mass spectrometry (SF-ICP-MS, Element XR Thermo Scientific). Samples were spiked with $1 \mu \mathrm{g} \mathrm{L}^{-1}$ indium (In) as an internal standard to correct for instrument drift. Three certified reference materials (PACS 3, MESS 4 and BCR 414) were processed as samples and analyzed for pCd and $\mathrm{P}$ to assess the accuracy of the methodology (Table 2). The certified reference materials yielded mean percentage recoveries of 108, 188, and $115 \%$ for pCd and 100, 106, and 95\% for P (PACS 3, MESS 4, and BCR 414, respectively). Blanks were determined by digesting and analyzing unused acid washed filters $(n=5)$. The detection limits, defined as three times the standard deviation of the blanks, for pCd and $\mathrm{P}$ were $0.07 \mathrm{pmol} \mathrm{kg}^{-1}$ and $0.03 \mathrm{nmol} \mathrm{kg}{ }^{-1}$, respectively $(n=5)$.
TABLE 2 | Results for pCd and P from the ICP-MS analysis of PACS 3, MESS 4, and BCR 414 certified references materials.

\begin{tabular}{|c|c|c|}
\hline & pCd & $\mathbf{P}$ \\
\hline & $\mu \mathrm{mol} \mathbf{k g}^{-1}$ & $\mathrm{mmol} \mathrm{kg}^{-1}$ \\
\hline \multicolumn{3}{|l|}{ PACS 3} \\
\hline Certified & $19.84 \pm 1.16$ & $29.38 \pm 2.91$ \\
\hline Measured & $21.32 \pm 0.44$ & $29.41 \pm 0.31$ \\
\hline$\%$ recovery & 108 & 100 \\
\hline \multicolumn{3}{|l|}{ MESS 4} \\
\hline Certified & $2.49 \pm 0.36$ & $33.58 \pm 5.17$ \\
\hline Measured & $4.69 \pm 1.21$ & $35.58 \pm 0.51$ \\
\hline$\%$ recovery & 188 & 106 \\
\hline \multicolumn{3}{|l|}{ BCR 414} \\
\hline Certified & $3.41 \pm 0.12$ & $428.84 \pm 51.20$ \\
\hline Measured & $3.93 \pm 0.60$ & $409.34 \pm 52.14$ \\
\hline$\%$ recovery & 115 & 95 \\
\hline Filter blank $(n=5)$ & $0.09 \mathrm{pmol} \mathrm{kg}^{-1}$ & $0.08 \mathrm{nmol} \mathrm{kg}^{-1}$ \\
\hline Limit of detection & $0.07 \mathrm{pmol} \mathrm{kg}^{-1}$ & $0.03 \mathrm{nmol} \mathrm{kg}^{-1}$ \\
\hline
\end{tabular}

Filter blanks as well as ICP-MS limit of detection are also shown.

\section{RESULTS}

\section{Hydrographic Setting Frontal Positions}

The transect intersected several frontal systems which, in turn, separated the study area into physically and biogeochemically distinct regions (Figure 1A). Frontal positions were determined previously (Weir et al., 2020) following temperature, salinity and oxygen criteria outlined in the literature (Orsi et al., 1995; Belkin and Gordon, 1996; Pollard et al., 2002). The Subtropical Front (STF) located at $42.4^{\circ} \mathrm{S}$, defined the boundary between the Subtropical Zone (STZ) to the north and the Subantarctic Zone (SAZ) to the south. The Subantarctic Front (SAF) was identified at $46.2^{\circ} \mathrm{S}$ and separated the SAZ in the north from the Polar Frontal Zone (PFZ) to the south which was bounded in the south by the Antarctic Polar front (APF) at $49.3^{\circ} \mathrm{S}$. Further south, the Antarctic Zone (AAZ) extended until the Southern Boundary (SBdy) at $58.5^{\circ} \mathrm{S}$, incorporating the southern Antarctic Circumpolar Current Front (sACCF) at $56.5^{\circ} \mathrm{S}$. The Marginal Ice Zone (MIZ), defined by $30 \%$ ice cover, was encountered at $61.7^{\circ} \mathrm{S}$ (de Jong et al., 2018). The location of the sample stations meant that, from north to south, station IO08 was found in the STZ, stations IO07 and IO06 in the SAZ, station IO05 in the PFZ and stations IO04, IO02, and IO01 were within the AAZ.

\section{Water Mass Classification}

Water masses (Figure 1B) were identified using potential temperature, salinity and oxygen criteria outlined in the literature (Orsi et al., 1995; Anilkumar et al., 2006). The high temperature and salinity signature of surface waters at the northernmost station reflected Subtropical Surface Water (STSW; $>12^{\circ} \mathrm{C}, \mathrm{S}>35.3$ ). Moving southward, the decrease in surface water temperature marked the transition from STSW to Subantarctic Surface Water (SASW; 7-12 ${ }^{\circ} \mathrm{C}$ ) and Antarctic Surface Water (AASW; $-1-2.5^{\circ} \mathrm{C}$ ). Below the surface 
waters in the STZ, a layer of South Indian Central Water (SICW) was sampled. This water mass was underlain by the northwards subducting Subantarctic Mode Water (SAMW; $12-15^{\circ} \mathrm{C} ; 26.2-26.6 \mathrm{~kg} \mathrm{~m}^{-3}$ ) which was sampled between $\sim 300-500 \mathrm{~m}$ at $41^{\circ} \mathrm{S}$. Similarly, Antarctic Intermediate Water (AAIW; $2.5-5.0^{\circ} \mathrm{C}, 26.7-27.4 \mathrm{~kg} \mathrm{~m}^{-3}$ ) was found subducting northwards below SAMW. In contrast to the intermediate waters, sampled deep waters consisted predominantly of southward upwelling Upper Circumpolar Deep Water (UCDW) and the deeper lying North Atlantic Deep Water (NADW) and Lower Circumpolar Deepwater (LCDW). The UCDW (27.2-27.8 kg $\mathrm{m}^{-3}$ ) was further characterized by oxygen minima (155$180 \mu \mathrm{mol} \mathrm{kg}{ }^{-1}$ ) and $\mathrm{PO}_{4}$ maxima (2.1-2.6 $\mu \mathrm{mol} \mathrm{kg} \mathrm{kg}^{-1}$ ). North of the APF, NADW (27.0-27.9 $\mathrm{kg} \mathrm{m}^{-3}$ ) was identified by high salinity $(S>34.7)$ and deep $\mathrm{PO}_{4}$ minima (1.9$2.3 \mu \mathrm{mol} \mathrm{kg}^{-1}$ ) while LCDW (27.8-27.9 $\mathrm{kg} \mathrm{m}^{-3}$ ), sampled below UCDW and NADW, was characterized by lower temperatures $\left(\sim 1^{\circ} \mathrm{C}\right)$. Finally, Antarctic Bottom Waters (AABW; 27.8$27.9 \mathrm{~kg} \mathrm{~m}^{-3}$ ), distinguished by characteristic local temperature minimums $\left(-0.5-1.0^{\circ} \mathrm{C}\right)$ were sampled at depth in the AAZ (IO02 and IO04).

\section{Surface Mixed Layer (SML) and Euphotic Depth}

The SML at each station was defined as the depth interval between the sea surface and the Mixed Layer Depth (MLD) which was calculated as the depth (between 10 and $400 \mathrm{~m}$ ) at which the Brunt Väisälä frequency (BVF) squared reaches a maximum while the euphotic zone depth was approximated as the depth at which $1 \%$ of surface PAR was measured (Weir et al., 2020). The MLD was shallowest at $122 \mathrm{~m}$ in the STZ, deepest in the SAZ at 190-220 $\mathrm{m}$ and intermediate in the PFZ (134 m) and AAZ (125$161 \mathrm{~m})$. The euphotic zone depth was always shallower than the MLD and generally shoaled northwards from $>56 \mathrm{~m}$ in the AAZ to $18 \mathrm{~m}$ in the STZ.
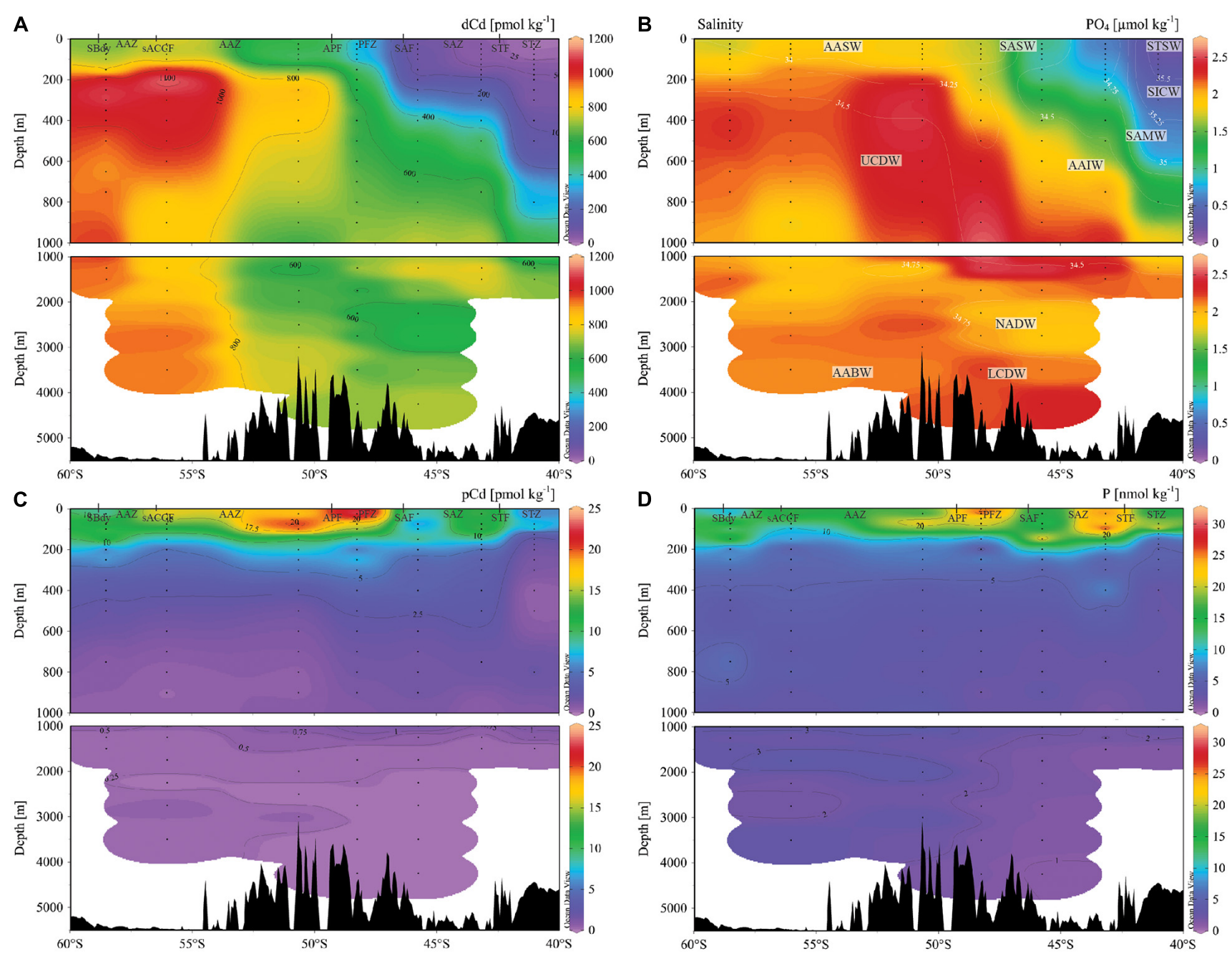

FIGURE 2 | Section plots of (A) dCd, (B) $\mathrm{PO}_{4}$ overlain by salinity, (C) pCd and (D) P. Each figure is separated into upper 1,000 m (upper panel) and below 1,000 m (bottom panel). Frontal positions, corresponding zones and water masses are shown (see Figure $\mathbf{1}$ for acronyms). Figure constructed using Ocean Data View (ODV; Schlitzer, 2020). $\mathrm{PO}_{4}$ data from Weir et al. (2020). 


\section{Distribution of Dissolved Elements Dissolved Cadmium}

Depth profiles of $\mathrm{dCd}$ concentrations along the transect are shown in Figure 2A and Supplementary Figure 1. At each station, dCd profiles displayed typical nutrient-type behavior consistent with low surface concentrations and increased concentrations at depth. Across the transect, dCd was fairly uniform in the SML and was characterized by a strong northsouth gradient which was associated with the frontal positions. Within the SML, dCd concentrations were $10 \pm 2 \mathrm{pmol} \mathrm{kg}^{-1}$ in the STZ and increased rapidly across the APF to $749 \pm 16 \mathrm{pmol}$ $\mathrm{kg}^{-1}$ in the southern AAZ. The difference between surface and deep water concentrations was most apparent at the northern stations and decreased southwards. For example, the mean dCd in STSW was $33 \pm 21 \mathrm{pmol} \mathrm{kg} \mathrm{kg}^{-1}, \sim 20$ times lower than the concentration of $688 \mathrm{pmol} \mathrm{kg}^{-1}(n=1)$ in UCDW. At the southernmost station, this factor was $\sim 1.4$ between AASW $\left(713 \pm 30 \mathrm{pmol} \mathrm{kg}^{-1}\right)$ and UCDW $\left(1018 \pm 65 \mathrm{pmol} \mathrm{kg}{ }^{-1}\right)$. Middepth maxima in $\mathrm{dCd}$ varied in concentration and with depth and coincided with local maxima in $\mathrm{PO}_{4}$ and minima in $\mathrm{O}_{2}$. The mid-depth dCd maximum ranged between $700 \mathrm{pmol} \mathrm{kg}^{-1}$ at $1,250 \mathrm{~m}$ depth in the STZ and $1,150 \mathrm{pmol} \mathrm{kg}^{-1}$ at $200 \mathrm{~m}$ depth in the AAZ. Below the mid-depth peak, concentrations were typically lower in NADW (598 $\left.\pm 47 \mathrm{pmol} \mathrm{kg}^{-1}\right)$ and showed increases in the LCDW $\left(800 \pm 120 \mathrm{pmol} \mathrm{kg}^{-1}\right)$ and AABW $\left(856 \pm 88 \mathrm{pmol} \mathrm{kg}^{-1}\right)$.

\section{Dissolved Phosphate}

Major nutrient concentrations have been reported previously (Weir et al., 2020). Here we briefly describe the distribution of $\mathrm{PO}_{4}$ (Figure 2B and Supplementary Figure 2) because of the extensive reference made to the $\mathrm{dCd}-\mathrm{PO}_{4}$ relationship. There was a strong southward increase in $\mathrm{SML} \mathrm{PO}_{4}$ concentrations, from $0.28 \pm 0.08 \mu \mathrm{mol} \mathrm{kg}{ }^{-1}$ in STSW to $1.85 \pm 0.09 \mu \mathrm{mol}$ $\mathrm{kg}^{-1}$ in AASW. Below the SML, $\mathrm{PO}_{4}$ increased to maximum concentrations in UCDW at each station. The intermediate depth $\mathrm{PO}_{4}$ maximum was most evident around the APF where $\mathrm{PO}_{4}$ reached $2.43 \pm 0.16 \mu \mathrm{mol} \mathrm{kg}{ }^{-1}$. The underlying NADW $\left(2.10 \pm 0.16 \mu \mathrm{mol} \mathrm{kg}{ }^{-1}\right)$ and $\operatorname{LCDW}\left(2.14 \pm 0.14 \mu \mathrm{mol} \mathrm{kg}{ }^{-1}\right)$ were characterized by local $\mathrm{PO}_{4}$ minima before slight increases in $\mathrm{PO}_{4}$ in $\mathrm{AABW}\left(2.20 \pm 0.02 \mu \mathrm{mol} \mathrm{kg}{ }^{-1}\right)$.

\section{Distribution of Particulate Elements}

\section{Particulate Cadmium}

The depth profiles of pCd (Figure 2C and Supplementary Figure 1) generally showed the opposite vertical distribution in comparison to dCd. Highest pCd concentrations were typically found within the surface water masses at each station, while strong negative gradients through subsurface water masses resulted in $\mathrm{pCd}$ concentrations having uniformly low $(<1 \mathrm{pmol}$ $\mathrm{kg}^{-1}$ ) concentrations below 1,000 $\mathrm{m}$ at all stations. UCDW, LCDW, and AABW had mean pCd concentrations of $1.34 \pm 1.08$, $0.35 \pm 0.21$, and $0.39 \pm 0.12 \mathrm{pmol} \mathrm{kg}^{-1}$, respectively. In the SML, mean pCd was highest near the APF (St. $48^{\circ} \mathrm{S}$; $18.83 \pm 3.76 \mathrm{pmol}$ $\mathrm{kg}^{-1}$ ), and generally decreased with distance north and south of this maximal zone. To the north, mean pCd in the SML of the
STZ was $6.18 \pm 3.49 \mathrm{pmol} \mathrm{kg}^{-1}$ and $9.44 \pm 2.90 \mathrm{pmol} \mathrm{kg}^{-1}$ in the SAZ. To the south, mean pCd in the SML of the AAZ was $14.72 \pm 4.04 \mathrm{pmol} \mathrm{kg}^{-1}$.

\section{Particulate Phosphorus}

The depth profiles of $\mathrm{P}$ (Figure 2D and Supplementary Figure 2) resembled those of $\mathrm{pCd}$ whereby surface waters were characterized by high $\mathrm{P}$ concentrations which decreased rapidly in subsurface water masses to extremely low values at depth. Like pCd, highest SML P concentrations (14.29 \pm 1.78 nmol kg-1) were measured near the APF. North of the APF, concentrations in the SML ranged between $9.77 \pm 3.26$ and $12.84 \pm 4.49 \mathrm{nmol} \mathrm{kg}^{-1}$ in the SAZ and STZ, respectively. South of the APF, concentrations in the SML were between $8.54 \pm 1.19$ and $12.98 \pm 0.53 \mathrm{nmol} \mathrm{kg}{ }^{-1}$. At greater depths, mean $\mathrm{P}$ concentrations in UCDW, LCDW, and AABW were $2.47 \pm 1.40,1.93 \pm 0.87$, and $1.48 \pm 0.25 \mathrm{nmol} \mathrm{kg}^{-1}$, respectively.

\section{DISCUSSION}

\section{Comparison With Previously Reported dCd and $\mathrm{pCd}$ Global Comparison}

The data presented here contributes the first measurements of $\mathrm{dCd}$ and $\mathrm{pCd}$ from the $30^{\circ} \mathrm{E}$ longitude in the Indian sector of the Southern Ocean and one of only a handful of winter trace metal datasets produced globally, thus closing key spatial and seasonal gaps in the global database. For comparative purposes, a global compilation of dCd and pCd measurements (Figures 3A-D) has been created from all available data included in the GEOTRACES Intermediate Data Product (IDP) 2017 (Schlitzer et al., 2018; see figure caption for full list of references). For dCd, our Southern Ocean data fell within the range of concentrations found in other ocean basins. Globally, the majority of vertical ocean profiles of dCd showed surface minima, from $0.04 \mathrm{pmol} \mathrm{kg}^{-1}$ in the Mediterranean Sea (Gerringa et al., unpublished) to $36 \mathrm{pmol}$ $\mathrm{kg}^{-1}$ in the Atlantic Southern Ocean (Baars et al., 2014). Below the surface, most vertical ocean profiles displayed intermediate to deep dCd maxima, from $368 \mathrm{pmol} \mathrm{kg}^{-1}$ in the Mediterranean Sea (Gerringa et al., unpublished) to $1,246 \mathrm{pmol} \mathrm{kg}^{-1}$ in the North Pacific Ocean (Minami et al., 2015). For the full depth profiles, our Southern Ocean dCd data had a range of 9-1,150 $\mathrm{pmol} \mathrm{kg}^{-1}$ which compared most similarly to that of the Atlantic Southern Ocean (36-970 pmol kg-1; Baars et al., 2014) and Indian Ocean (10-1,100 pmol kg-1; Thi Dieu Vu and Sohrin, 2013). For pCd, our Southern Ocean data fell within the range of concentrations found in other ocean basins and most closely resembled those observed in the South Atlantic, particularly in the upper 1,000 m. Highest pCd concentrations were found in surface waters of all datasets while extremely low values, between $0.02 \mathrm{pmol} \mathrm{kg}^{-1}$ (South Atlantic; Henderson et al., unpublished) and $0.06 \mathrm{pmol}$ $\mathrm{kg}^{-1}$ (this study) characterized deep ocean distributions. For the upper $1,000 \mathrm{~m}$, mean pCd concentrations were between 1.13 and $5.04 \mathrm{pmol} \mathrm{kg}^{-1}$ in the North Atlantic (Hayes et al., 2018) and Equatorial Pacific (Lee et al., 2018), respectively, while the mean value for our Southern Ocean data was $5.92 \mathrm{pmol} \mathrm{kg}^{-1}$. 
A

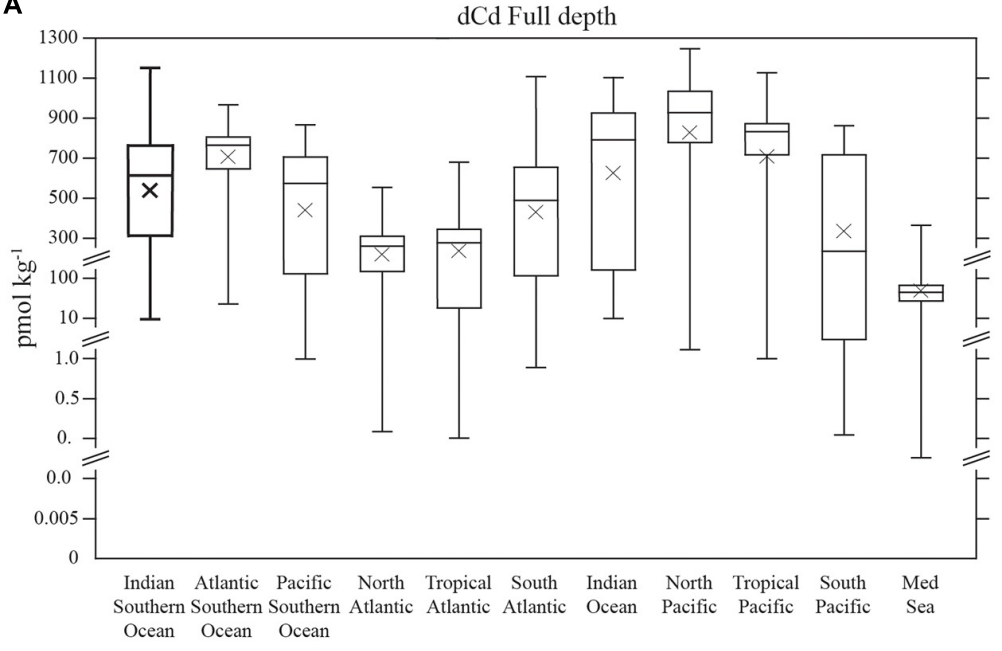

C

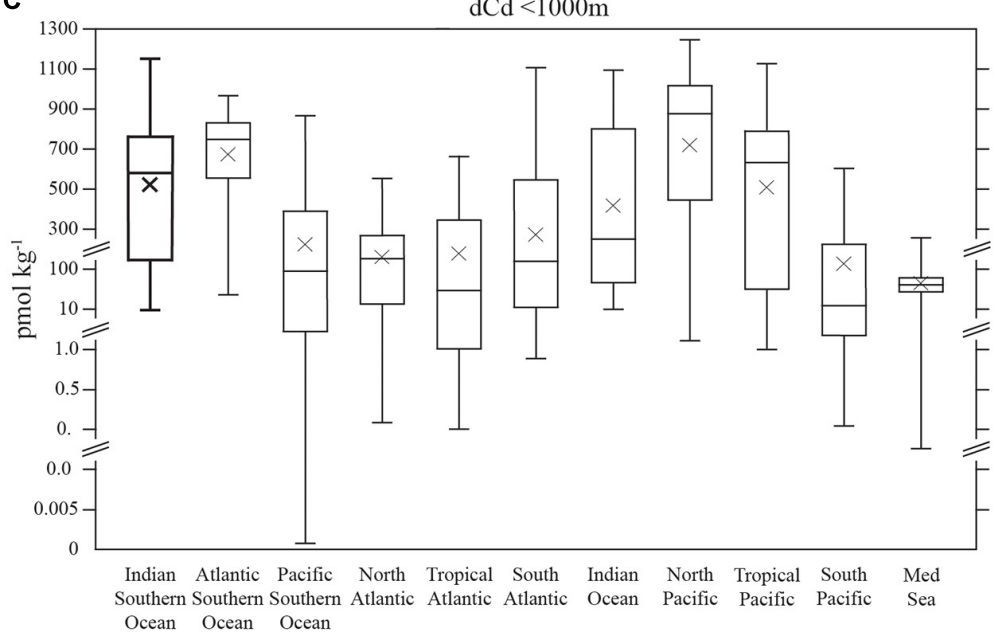

B

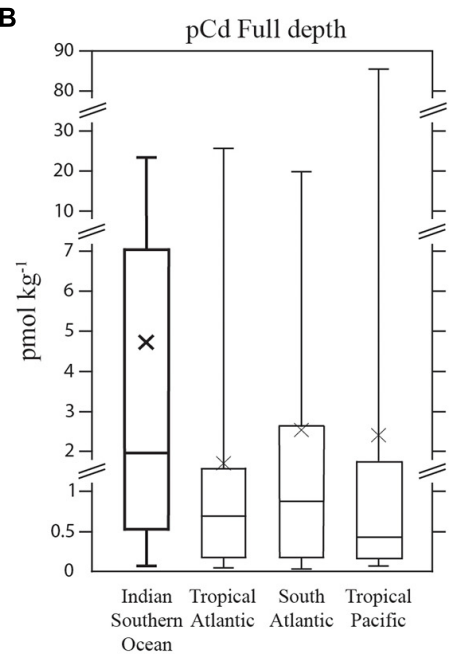

D

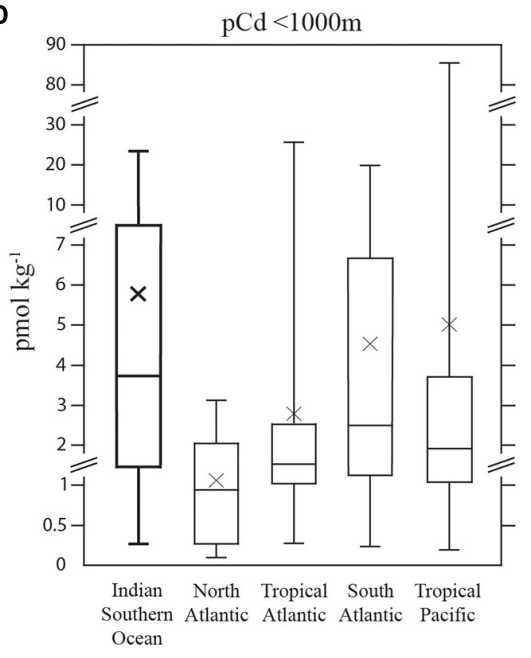

FIGURE 3 | Box and whisker plots of (A) dCd for full depth profiles, (B) pCd for full depth profiles, (C) dCd for profiles to 1,000 m and (D) pCd for profiles to 1,000 m. Data compiled from all available data from the GEOTRACES intermediate data product (IDP) 2017 (Schlitzer et al., 2018). Plots in bold are data from this study. From bottom to top, plots are structured as follows: minimum, quartile 1, median, quartile 3, maximum. The cross $(x)$ represents the mean value. Note the changes in the vertical scale. For dCd data references are as follows, Indian Southern Ocean data [this study ( $n=132$ full depth; $103<1,000$ m)], Atlantic Southern Ocean [transect GIPY05 ( $n=177$ full depth; $116<1,000$ m) (Baars et al., 2014)], Pacific Southern Ocean [transect GIPY06 ( $n=82$ full depth; $223<1,000 \mathrm{~m})$ (Butler et al., 2013), transect GIPY02 ( $n=0$ full depth; $109<1,000 \mathrm{~m}$ ) (Butler et al., 2013), transect GPpr01 ( $n=0$ full depth; $34<1,000 \mathrm{~m})$ (Hassler and Ellwood, unpublished), transect GPpr02 ( $n=77$ full depth; $168<1,000 \mathrm{~m}$ (Ellwood, 2008)], North Atlantic Ocean [transect GA02 ( $n=407$ full depth; $227<1,000 \mathrm{~m})$ (Middad et al., 2018), transect GA03 ( $n=588$ full depth; $303<1,000 \mathrm{~m}$ ) (Hayes et al., 2018)], Tropical Atlantic Ocean [transect GA02 $(n=479$ full depth; $259<1,000 \mathrm{~m}$ ) (Middag et al., 2018), transect GA11 ( $n=57$ full depth; $27<1,000 \mathrm{~m}$ ) (Xie et al., 2018)], South Atlantic Ocean [transect GA02 ( $n=482$ full depth; $261<1,000 \mathrm{~m}$ ) (Xie et al., 2015; Middag et al., 2018), transect GA10 ( $n=340$ full depth; $159<1,000$ m (Achterberg et al., unpublished), transect GIPY04 ( $n=86$ full depth; $103<1,000 \mathrm{~m}$ ) (Boye et al., 2012)], Indian Ocean [transect Gl04 ( $n=167$ full depth; $94<1,000 \mathrm{~m}$ ) (Thi Dieu Vu and Sohrin, 2013)], North Pacific Ocean [transect GP02 ( $n=256$ full depth; $137<1,000 \mathrm{~m}$ ) (Minami et al., 2015), transect GP18 ( $n=94$ full depth; $49<1,000 \mathrm{~m})$ (Minami et al., 2015$)$, transect GPpr07 ( $n=25$ full depth; $68<1,000 \mathrm{~m}$ ) (Janssen et al., 2017)], Tropical Pacific Ocean [transect GP16 ( $n=667$ full depth; $350<1,000 \mathrm{~m})$ (John et al., 2017)], South Pacific Ocean [transect GP13 ( $n=342$ full depth; $544<1,000 \mathrm{~m}$ ) (Bowie et al., unpublished)] and Mediterranean Sea [transect GA04 ( $n=1376$ full depth; 1,057 < 1,000 m) (Gerringa et al., unpublished)]. For pCd, references are as follows, Indian Southern Ocean data [this study $(n=122$ full depth; $94<1,000 \mathrm{~m})$ ], North Atlantic Ocean [transect GA03 ( $n=0$ full depth; $34<1,000 \mathrm{~m}$ ) (Hayes et al., 2018)], Tropical Atlantic Ocean [transect GA06 ( $n=103$ full depth; $82<1,000 \mathrm{~m}$ ) (Achterberg, unpublished)], South Atlantic Ocean [transect GA10 ( $n=231$ full depth; $134<1,000 \mathrm{~m}$ ) (Henderson et al., unpublished)] and Tropical Pacific Ocean [transect GP16 ( $n=703$ full depth; $397<1,000 \mathrm{~m})$ (Lee et al., 2018)].

\section{Southern Ocean dCd Comparison}

Considering only surface ( $\sim 25 \mathrm{~m}) \mathrm{dCd}$ measurements allowed for some interesting observations to be made regarding interbasin and seasonal differences within the Southern Ocean (Figure 4). At the lower latitudes (north of $\sim 45^{\circ} \mathrm{S}$ ), surface
dCd was low across all datasets (Figure 4A) and our winter concentrations (9-34 pmol $\mathrm{kg}^{-1}$ ) were most similar to those measured in the Pacific sector of the Southern Ocean (17-23 pmol kg-1). At the higher latitudes (south of $\sim 45^{\circ} \mathrm{S}$ ), surface dCd increased rapidly across all datasets. 


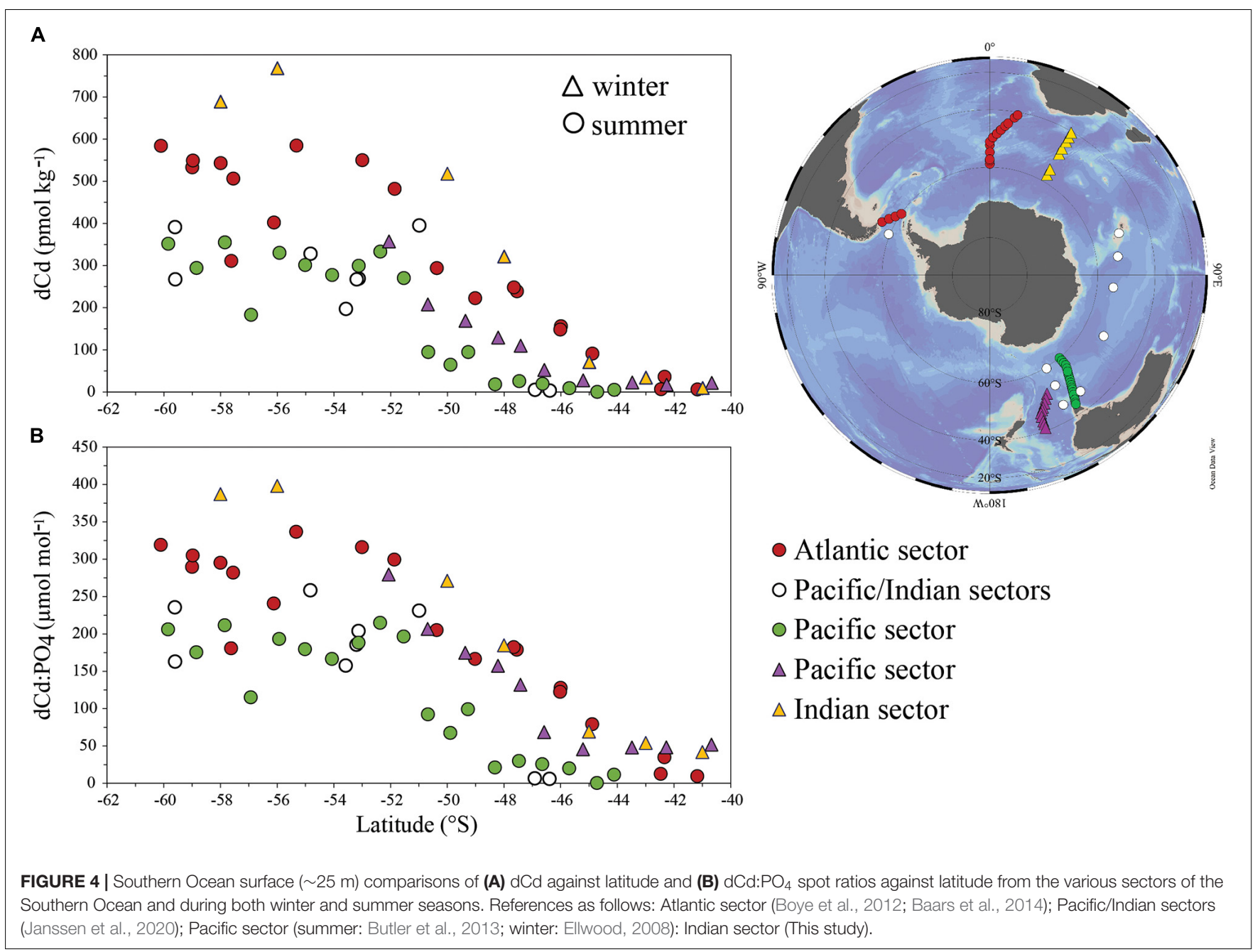

While the sharpest dCd increase was observed in the winter Indian sector of the Southern Ocean, $\mathrm{dCd}: \mathrm{PO}_{4}$ spot ratios calculated for all datasets were more comparable (Figure 4B), particularly for the Pacific sector (winter and summer) and Indian sector (winter) of the Southern Ocean, suggesting dCd increases were proportional to increases in $\mathrm{PO}_{4}$. Between $55^{\circ} \mathrm{S}$ and $60^{\circ} \mathrm{S}$ there was a decoupling between winter (only Indian sector dataset considered as the Pacific sector measurements stop at $52^{\circ} \mathrm{S}$ ) and summer $\mathrm{dCd}: \mathrm{PO}_{4}$ whereby winter ratios were considerably higher. These seasonal differences are likely caused by two primary mechanisms. First, intense summer productivity at the higher latitudes is driven by diatoms with high intracellular pCd:P (Baars et al., 2014) causing reduced surface $\mathrm{dCd}$ and $\mathrm{dCd}: \mathrm{PO}_{4}$ compared to winter values. Second, deep winter mixing provides access to subsurface water masses with enriched $\mathrm{dCd}: \mathrm{PO}_{4}$ signatures (from diatom remineralisation and regional upwelling of UCDW with high dCd:PO $\mathrm{PO}_{4}$; see section "Physical Resupply of dCd Through Upwelling and Deep Winter Mixing”) thereby preferentially enriching surface waters with additional $\mathrm{dCd}$. While these comparisons do present interesting insights into the seasonal cycling of $\mathrm{dCd}$, interpretations should be made with caution considering that the data are not direct seasonal crossover comparisons.

\section{Distribution of dCd and pCd in the Upper Water Column Relation With $\mathrm{PO}_{4}$ and $\mathrm{P}$}

Seawater samples were collected in early to mid-July and therefore represent early winter conditions. Owing to increased surface mixing and decreased light exposure (Dong et al., 2008; Swart et al., 2015), the winter months are generally considered biologically dormant in comparison to the spring and summer months. However, estimates of relative productivity (inferred from measurements of Chl- $a$; Supplementary Figure 3), were comparable to spring measurements and were at the lower end of summer measurements (Weir et al., 2020). For example, north of the APF, our early winter (July) Chl-a concentrations averaged over the SML (0.31-0.54 $\left.\mu \mathrm{g} \mathrm{kg}^{-1}\right)$ were similar to Chl- $a$ concentrations measured to the east during spring $\left(0.34 \mu \mathrm{g} \mathrm{kg}^{-1}\right.$; Becquevort et al., 2000) and summer (0.39-1.23 $\mu \mathrm{g} \mathrm{kg}^{-1}$; Rembauville et al., 2016). In the AAZ, our SML Chl-a $\left(0.20-0.30 \mu \mathrm{g} \mathrm{kg}^{-1}\right)$ was within the range of previous spring 
concentrations (0.10-0.39 $\mu \mathrm{g} \mathrm{kg}^{-1}$; Becquevort et al., 2000) and below previous summer concentrations (0.49-0.98 $\mu \mathrm{g} \mathrm{kg}^{-1}$; Rembauville et al., 2016). This suggests that the winter euphotic layer was not biologically dormant (Weir et al., 2020) and that biological uptake by phytoplankton could potentially play an important role in controlling $\mathrm{dCd}$ and $\mathrm{pCd}$ distributions during winter.

The distribution of $\mathrm{Cd}$ and $\mathrm{P}$ were closely correlated across the transect, particularly in the upper water column (above the depth of the $\mathrm{O}_{2}$ minimum) where a strong linear relationship between dCd vs. $\mathrm{PO}_{4}\left[\mathrm{dCd}\left(\mathrm{pmol} \mathrm{kg}{ }^{-1}\right)=431 \pm 44 \mathrm{PO}_{4}(\mu \mathrm{mol}\right.$ $\left.\left.\mathrm{kg}^{-1}\right)-198 ; r^{2}=0.89 ; n=93\right]$ and pCd vs. $\mathrm{P}$ [pCd (pmol $\left.\left.\mathrm{kg}^{-1}\right)=0.65 \pm 0.11 \mathrm{P}\left(\mathrm{nmol} \mathrm{kg}{ }^{-1}\right)+0.40 ; r^{2}=0.86 ; n=85\right]$ was observed. Assuming that all $\mathrm{P}$ is of biogenic origin, and considering the close coupling of $\mathrm{pCd}$ and $\mathrm{P}$, it is reasonable to assume that $\mathrm{pCd}$ is majorly biogenic in composition. Low $\mathrm{dCd}$ and $\mathrm{PO}_{4}$ concentrations near the ocean surface and enrichments in subsurface waters are widely accepted to result from biological uptake by phytoplankton in the euphotic zone and subsequent remineralisation at depth (Abouchami et al., 2014; Baars et al., 2014; Sieber et al., 2019; Janssen et al., 2020). Biological uptake and assimilation of $\mathrm{dCd}$ and $\mathrm{PO}_{4}$ drives the production of organic pCd and $\mathrm{P}$ as observed by the high surface $\mathrm{pCd}$ and $P$ concentrations at each station (Figure 2 and Supplementary Figures 1, 2). Furthermore, vertical profiles of pCd co-varied with those of Chl- $a$ in the upper $150 \mathrm{~m}$ and pCd maxima were either at or very close to the depth of the Chl- $a$ maxima (Supplementary Figure 3). In the subsurface, decreasing pCd and $\mathrm{P}$ concentrations correspond to generally increasing $\mathrm{dCd}$ and $\mathrm{PO}_{4}$ concentrations partly reflecting the aerobic remineralisation of sinking phytoplankton cells by the microbial community. The extremely low $\left(<1 \mathrm{pmol} \mathrm{kg}^{-1}\right)$ concentrations of $\mathrm{pCd}$, and relatively high concentrations of $\mathrm{dCd}\left(>500 \mathrm{pmol} \mathrm{kg}{ }^{-1}\right)$, below $1,000 \mathrm{~m}$ suggests that variations in Cd distributions at depth were primarily controlled by the advection of water masses (with preformed Cd signatures) into the sampling region and were therefore not related to local particle transformations.

\section{Cd Uptake Influenced by the Availability of Dissolved $\mathrm{Cd}$ and Other Metals (Fe, Zn, and Mn)}

The availability of $\mathrm{Cd}$ and the relative availability of several essential trace metals (e.g., Fe, $\mathrm{Zn}$, and $\mathrm{Mn}$ ) has been shown to impact Cd uptake and therefore directly influence phytoplankton pCd:P stoichiometries (Price and Morel, 1990; Lee and Morel, 1995; Sunda and Huntsman, 2000; Cullen and Sherrell, 2005; Middag et al., 2018). In an effort to better understand the link between $\mathrm{Cd}$ uptake and the availabilities of $\mathrm{Cd}, \mathrm{Fe}, \mathrm{Zn}$ and $\mathrm{Mn}$, we compare surface $(\sim 25 \mathrm{~m})$ pCd:P with $\mathrm{dCd}$ and dissolved ratios of $\mathrm{Cd}$ to $\mathrm{Fe}$ (dCd:dFe), Cd to $\mathrm{Zn}$ (dCd:dZn) and $\mathrm{Cd}$ to Mn (dCd:dMn; Figure 5; see Supplementary Tables 1, 2 for validation of $\mathrm{dFe}, \mathrm{dZn}$, and $\mathrm{dMn})$. Ratios of $\mathrm{pCd}: \mathrm{P}$ were low in the STZ and SAZ (0.37-0.52 $\left.\mathrm{mmol} \mathrm{mol}^{-1}\right)$, increased in the PFZ $\left(0.86 \mathrm{mmol} \mathrm{mol}^{-1}\right)$ and were highest in the AAZ (0.91$\left.1.07 \mathrm{mmol} \mathrm{mol}^{-1}\right)$. In the STZ, dCd was $9 \mathrm{pmol} \mathrm{kg}^{-1}$ and increased roughly 80 -fold to $768 \mathrm{pmol} \mathrm{kg}^{-1}$ in the AAZ. All $\mathrm{dCd}$ :metal ratios were lowest in the STZ and increased at various rates through the SAZ and PFZ. In the PFZ, dCd:dZn was highest
(0.38 $\left.\mathrm{mol} \mathrm{mol}^{-1}\right)$ and decreased in the AAZ (0.18-0.23 mol $\left.\mathrm{mol}^{-1}\right)$ while $\mathrm{dCd}: \mathrm{dFe}\left(13.78-15.36 \mathrm{~mol} \mathrm{~mol}^{-1}\right)$ and $\mathrm{dCd}: \mathrm{dMn}$ (1.62-2.29 $\mathrm{mol} \mathrm{mol}^{-1}$ ) were highest in the AAZ.

The uptake of $\mathrm{Cd}$ by phytoplankton is directly related to the concentration of free (bioavailable) $\mathrm{dCd}$ and inversely related the concentration of free $d F e, d Z n$, and $d M n$. Since Mn forms only weak organic complexes, the bioavailable Mn concentration is assumed to be approximated by dMn (Sunda and Huntsman, 2000). For Cd and Zn, organic complexation may potentially impact biological uptake in the STZ and SAZ where $\mathrm{dCd}$ and $\mathrm{dZn}$ are inherently low, however, in the PFZ and AAZ, bioavailable $\mathrm{dCd}$ and $\mathrm{dZn}$ are high owing to increased concentrations which saturate metal binding ligands (Baars and Croot, 2011; Baars et al., 2014). For Fe, organic complexation dominates Fe speciation in the Southern Ocean (Croot et al., 2004) and, coupled with the low surface dFe (0.03$0.12 \mathrm{nmol} \mathrm{kg}{ }^{-1}$ ) measured throughout the transect, suggests that $\mathrm{dFe}$ was potentially at or near limiting concentrations. It follows that in regions with higher $\mathrm{dCd}$ and $\mathrm{dCd}$ :metal ratios, phytoplankton may assimilate more $\mathrm{Cd}$ relative to $\mathrm{P}$ providing at least one potential driver behind the elevated pCd:P in the PFZ and AAZ. While our data suggest dCd availability is the primary factor determining $\mathrm{Cd}$ uptake, as suggested previously (Middag et al., 2018), assessing the relative importance of the various $\mathrm{dCd}$ :metal ratios in influencing $\mathrm{pCd}: \mathrm{P}$ is more complex. Lowest $\mathrm{dFe}$ was measured in the AAZ (0.03-

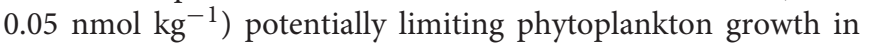
this region resulting in increased cellular $\mathrm{pCd}: \mathrm{P}$ via growth biodilution or increased uptake of $\mathrm{Cd}$ (relative to $\mathrm{P}$ ) through non-specific divalent metal transporters, a mechanism which is intensified under low Fe (Lane et al., 2009). In the PFZ, pCd:P was relatively high (comparable to the lower end of pCd:P in the AAZ) yet dCd:dFe was more than 4 fold lower than in the AAZ. Based on dCd:dFe alone, we would expect pCd:P in the PFZ to be much lower in comparison to the AAZ. However, dCd:dZn in the PFZ was almost two-fold higher than the AAZ and dCd:dMn was high (although not as high as values calculated for the AAZ) possibly indicating increased competition success for $\mathrm{dCd}$ over $\mathrm{dZn}$ (and possibly $\mathrm{dMn}$ ) or passive uptake of Cd to prevent toxicity (Horner et al., 2013) thereby increasing pCd:P ratios. In the northern AAZ, pCd:P was higher, and $\mathrm{dCd}$ lower, at $50^{\circ} \mathrm{S}$ compared to $56^{\circ} \mathrm{S}$, which contradicts the primary role for $\mathrm{dCd}$ availability in governing pCd:P. At both stations, $\mathrm{dCd}$ :dFe was equally high, however, $\mathrm{dFe}$ at $50^{\circ} \mathrm{S}\left(0.03 \mathrm{nmol} \mathrm{kg}^{-1}\right.$; the lowest surface value measured along the transect) was lower than at $56^{\circ} \mathrm{S}\left(0.05 \mathrm{nmol} \mathrm{kg}^{-1}\right)$ potentially limiting phytoplankton growth (and increasing pCd:P) at $50^{\circ} \mathrm{S}$ to a greater degree than $56^{\circ} \mathrm{S}$. Further south, dCd, pCd:P, and $\mathrm{dCd}: \mathrm{dFe}$ decreased between $56^{\circ} \mathrm{S}$ and $58^{\circ} \mathrm{S}$ and $\mathrm{dCd}: \mathrm{dZn}$ and $\mathrm{dCd}$ : $\mathrm{dMn}$ increased suggesting that, of the Cd:metal antagonisms considered as secondary controls (after the primary control by $\mathrm{dCd}$ ), the $\mathrm{dCd}: \mathrm{dFe}$ antagonism had the largest effect on $\mathrm{pCd}: \mathrm{P}$ variations in this region.

\section{Relating $\mathrm{pCd:P}$ to Phytoplankton Stoichiometry}

The literature regarding plankton metal stoichiometries in natural phytoplankton assemblages is scarce 


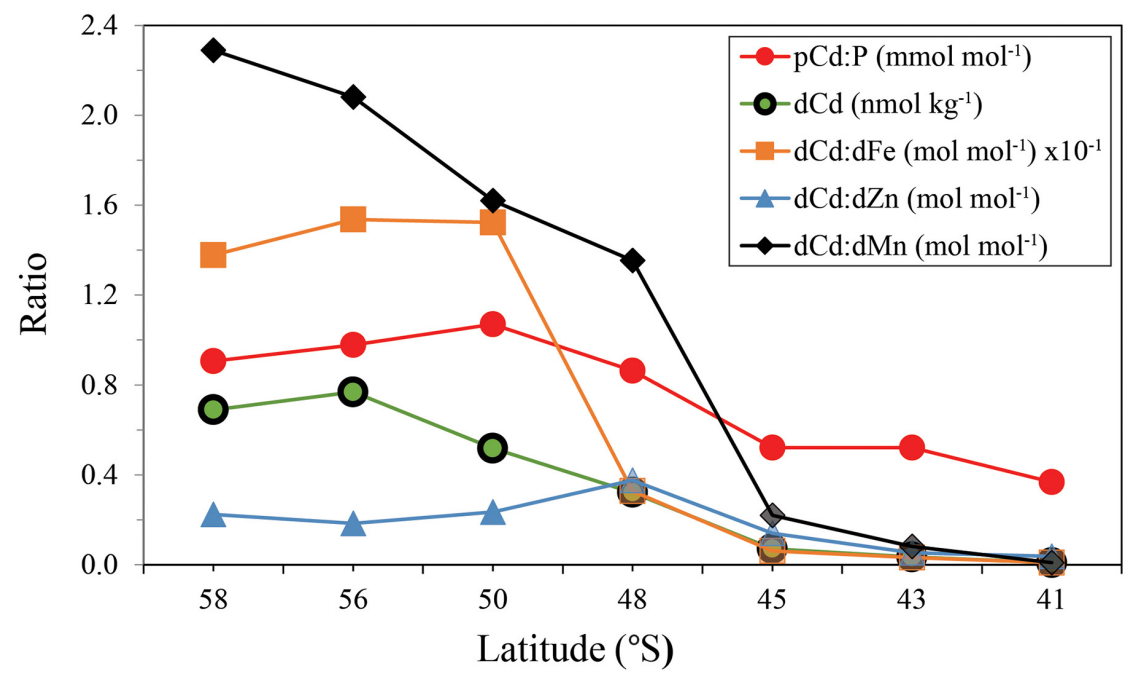

FIGURE 5 | Plot of dCd and pCd:P, dCd:dFe; dCd:dZn, and dCd:dMn spot ratios for surface waters ( 25 m) across the transect. Note: where necessary units were converted to plot on a single vertical axis for direct comparison.

(Twining and Baines, 2013). Nevertheless, phytoplankton cellular Cd quotas are reported to range by a factor of 100 (0.01-1 mmol mol $\mathrm{m}^{-1} \mathrm{P}$ ) compared to a factor of 20 for other bioactive metals such as $\mathrm{Fe}, \mathrm{Mn}, \mathrm{Zn}$, and $\mathrm{Cu}$ (Ho et al., 2003; Twining and Baines, 2013). We compare our surface water $(\sim 25 \mathrm{~m})$ pCd:P ratios with plankton derived $\mathrm{Cd}: \mathrm{P}$ ratios to assess whether or not the surface water particulate signature is a good representation of the observed phytoplankton community based on observed phytoplankton community data from this transect (Weir et al., 2020, Supplementary Figure 4). We acknowledge the limitations of such a comparison which include differences in oceanographic setting (e.g., open ocean vs. coastal upwelling) and inherent environmental conditions (e.g., oligotrophic vs. nutrient replete conditions, differences in resident phytoplankton community assemblage and grazing pressures by local zooplankton) which may influence $\mathrm{Cd}$ uptake systematics. Regardless, we find that $\mathrm{pCd}: \mathrm{P}$ do provide a reasonable estimation of the resident phytoplankton community. To illustrate, a flagellate-dominated assemblage from the North Atlantic had a pCd:P ratio of $0.51 \pm 0.09 \mathrm{mmol} \mathrm{mol}^{-1}$ (Kuss and Kremling, 1999), almost exactly matching our $\mathrm{pCd}: \mathrm{P}$ ratio from the flagellate-dominated SAZ stations $\left(0.52 \mathrm{mmol} \mathrm{mol}^{-1}\right.$ for both SAZ stations). However, these ratios were higher than the STZ $\left(0.37 \mathrm{mmol} \mathrm{mol}^{-1}\right)$ station and lower than the PFZ station $\left(0.86 \mathrm{mmol} \mathrm{mol}^{-1}\right)$ despite significant contributions from flagellates to the phytoplankton community at both stations. There was, however, a much larger contribution of diatoms relative to flagellates at the PFZ station compared to the STZ providing a potential driver of variations in $\mathrm{pCd}: \mathrm{P}$ whereby diatom growth rates have been shown to directly influence $\mathrm{pCd}: \mathrm{P}$ ratios while flagellates show no functional response in $\mathrm{pCd}: \mathrm{P}$ (Finkel et al., 2007). In the PFZ, changes in diatom growth rate, potentially due to the availability of other trace metals [see section "Cd Uptake Influenced by the Availability of Dissolved $\mathrm{Cd}$ and Other Metals (Fe, $\mathrm{Zn}$, and $\mathrm{Mn}$ )"], would therefore have a greater bearing on the total phytoplankton community $\mathrm{pCd}: \mathrm{P}$ ratio compared to the $\mathrm{STZ}$. In the $\mathrm{AAZ}$, the high $\mathrm{pCd}: \mathrm{P}$ ratios (0.91-1.07 mmol mol $\mathrm{m}^{-1}$ ) compared most similarly to a ratio from a diatom-dominated assemblage from the high latitude Southern Ocean (1.29 $\pm 0.07 \mathrm{mmol} \mathrm{mol}^{-1}$; Cullen et al., 2003) in agreement with our phytoplankton community assemblage data. The higher pCd:P ratios in the Cullen study could be the result of lower summer $\mathrm{dFe}$ and $\mathrm{dMn}$ concentrations $(0.03$ and $0.08 \mathrm{~mol}$ $\mathrm{kg}^{-1}$, respectively) which may decrease diatom growth rates (and therefore increase $\mathrm{pCd}: \mathrm{P}$ ) to a greater extent compared to winter.

\section{Remineralisation Length Scales of Cd and P}

In order to investigate remineralisation rates of $\mathrm{pCd}$ and $\mathrm{P}$ at each station, we plot $\mathrm{pCd}$ and $\mathrm{P}$ concentrations individually (as a percentage of their respective maximum concentrations at each station) with depth as well as corresponding $\mathrm{pCd}$ :P ratios with depth (Figures 6A-D). We show one representative profile for each Southern Ocean Zone (see Supplementary Figure 5 for all other stations and Supplementary Figure $\mathbf{6}$ for full depth profiles). Maximum pCd and $\mathrm{P}$ concentrations generally occurred at the same depth and were most commonly located between the euphotic depth and the base of the mixed layer (with an exception in the PFZ where maxima were co-located above the euphotic depth). We observe different trends in the vertical $\mathrm{pCd}: \mathrm{P}$ profiles across the transect. In the AAZ (Figure 6A), pCd:P increased to a subsurface maximum $\left(1.2 \mathrm{mmol} \mathrm{mol}^{-1}\right)$ at $100 \mathrm{~m}$, consistent with a preferential remineralisation of $\mathrm{P}$ over this depth range. Below the pCd:P maximum, ratios decreased rapidly and the relative concentrations of $\mathrm{pCd}$ and $\mathrm{P}$ suggest a preferential remineralisation of $\mathrm{Cd}$ at depth. These observations are consistent with previous findings in the AAZ of the Southern Ocean, and in high-nutrient, low-chlorophyll areas throughout the global ocean, where it was hypothesized that a labile $\mathrm{P}$ fraction (associated with ATP and DNA in the cell) is preferentially remineralised over $\mathrm{pCd}$ near the surface resulting in an increase 

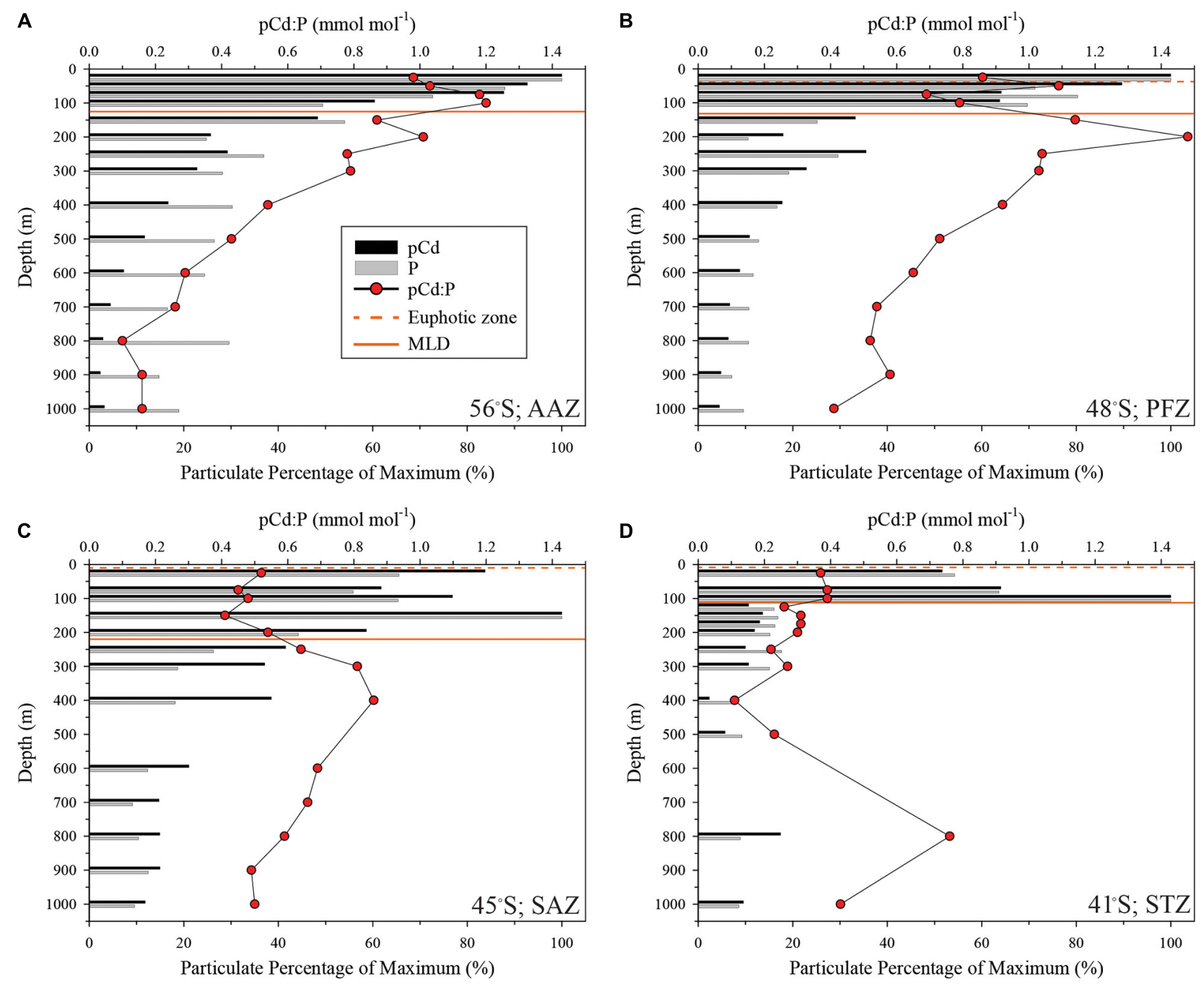

FIGURE 6 | Particulate cadmium (black bars) and P (gray bars) normalized to profile maximum values (bottom axis) for the upper 1,000 m in (A) the AAZ, (B) the PFZ, (C) the SAZ, and (D) the STZ. The red dots are the absolute pCd:P ratios at each depth (top axis). Dashed horizontal lines represents the bottom of the euphotic zone at each station. Solid horizontal line represents the bottom of the MLD at each station. No euphotic zone data for $56^{\circ} \mathrm{S}$ (AAZ) due to PAR sensor failure.

in pCd:P (Bourne et al., 2018). Below the pCd:P maximum, pCd is preferentially remineralised over a second, more labile, $\mathrm{P}$ fraction (associated with phospholipid membranes) causing a decrease in pCd:P through the mesopelagic zone (Bourne et al., 2018).

A major difference between vertical profiles of $\mathrm{pCd}: \mathrm{P}$ in the $\mathrm{AAZ}$ and those to the north was the rate at which $\mathrm{pCd}: \mathrm{P}$ decreased with depth below the subsurface maximum. For example, pCd:P in the AAZ decreased by a factor of 7.5 from a subsurface maximum of $1.2 \mathrm{mmol} \mathrm{mol}^{-1}$ to $0.16 \mathrm{mmol} \mathrm{mol}^{-1}$ at $1,000 \mathrm{~m}$. This factor was 3.6 in the PFZ (Figure 6B), 1.7 in the SAZ (Figure 6C) and 0.9 in the STZ (Figure 6D; there was no distinct $\mathrm{pCd}: \mathrm{P}$ maximum here although a local subsurface maximum at $100 \mathrm{~m}$ was evident). Since all vertical pCd:P profiles ultimately converge on relatively consistent deep water $(>1,500 \mathrm{~m})$ ratios, stations with higher ratios in surface waters (i.e., PFZ and AAZ) must decrease more rapidly, relative to depth, compared to stations in the SAZ and STZ. Vertical and latitudinal differences in pCd:P profile shapes may simply be related to intracellular $\mathrm{Cd}$ concentrations, which vary as a function of the availability of $\mathrm{Cd}$ and other metals [see section "Cd Uptake Influenced by the Availability of Dissolved Cd and Other Metals (Fe, $\mathrm{Zn}$, and $\mathrm{Mn}$ )"]. In addition, variations in $\mathrm{pCd}: \mathrm{P}$ profiles are potentially driven by the proportion of diatoms in the resident phytoplankton community. In the AAZ (diatom dominated), preferential remineralisation of $\mathrm{pCd}$ below the $\mathrm{pCd}: \mathrm{P}$ maximum will occur to a greater extent because of the elevated cellular pCd:P in diatoms. In the PFZ (diatom and flagellate dominated), SAZ (flagellate dominated), and STZ (flagellate dominated), the increasing contributions of flagellates, likely with lower cellular pCd:P compared to diatoms, provides a potential mechanism behind the slower rates of $\mathrm{pCd}$ remineralisation below the $\mathrm{pCd}: \mathrm{P}$ maximum. Data pertaining to taxonomic differences in $\mathrm{pCd}: \mathrm{P}$ are scarce and have not been equivocally demonstrated in the field. For other metals, however, notably for Fe, Mn, and $\mathrm{Zn}$, 
metal:P ratios of diatoms are higher than flagellates from the Southern Ocean (Twining and Baines, 2013) providing at least some support for a taxonomic effect on pCd:P. In addition to the near-surface pCd:P maximum, there is a secondary, deeper, maximum visible at the northern stations. This maximum deepens from $200 \mathrm{~m}$ at $48^{\circ} \mathrm{S}$ to $400 \mathrm{~m}$ at $45^{\circ} \mathrm{S}$ and $800 \mathrm{~m}$ at $41^{\circ} \mathrm{S}$ (Figures 6B-D) and appears to be spatially associated with isopycnals corresponding to AAIW (Figure 7A). This feature may represent the advection of particles with relatively high pCd:P from the upper water column of the PFZ along the northward subducting flow path of AAIW. However, not all profiles fit the described vertical behavior of pCd:P. For example, in the SAZ $\left(45^{\circ} \mathrm{S}\right)$, pCd:P decreased in the upper $150 \mathrm{~m}$, a direct contrast to the other stations. Here, and likely other stations

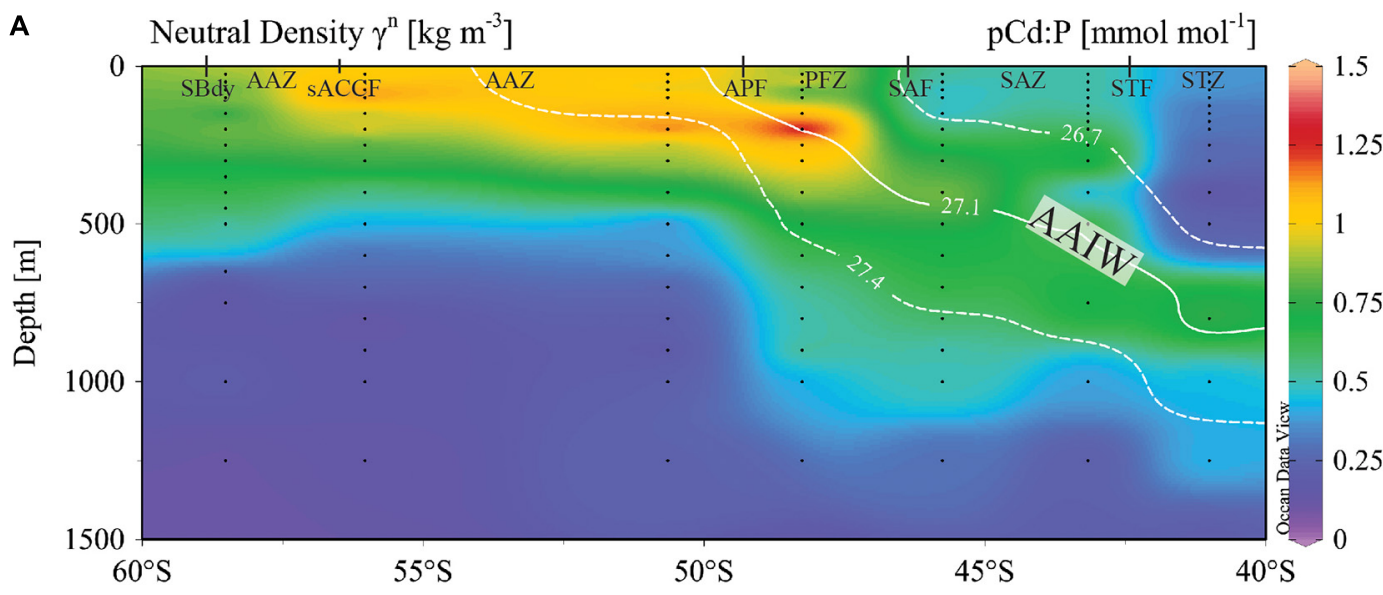

B
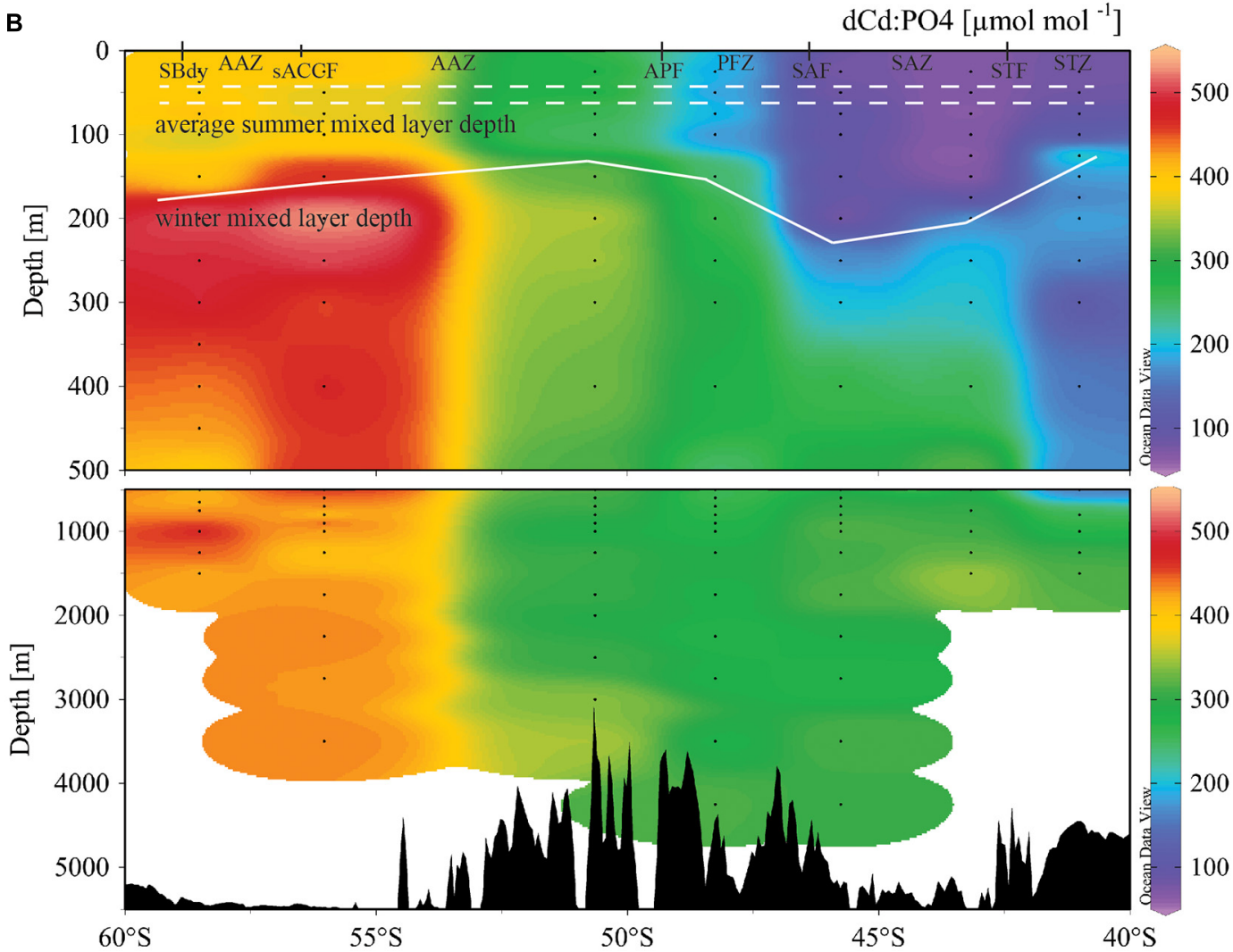

FIGURE 7 | Distribution plots of (A) pCd:P spot ratios for the upper 1,500 $\mathrm{m}$ and (B) dCd:PO $\mathrm{P}_{4}$ spot ratios separated into upper $500 \mathrm{~m}$ (upper panel) and below $500 \mathrm{~m}$ (bottom panel). Frontal position and corresponding zones are shown. In (A), the solid white line is the median isopycnal defining Antarctic Intermediate Water (AAIW) and the dashed white lines are the upper and lower isopycnal limits for AAIW. In (B), dotted lines represent the average range of the summer mixed layer depth [data from WOCE Global Data Resource (2018)]. Solid line represents the calculated winter mixed layer depth during this study. Figure constructed using Ocean Data View (ODV; Schlitzer, 2020). 
where deviations from general trends are evident, $\mathrm{pCd}: \mathrm{P}$ may include signatures of dead organic matter, bacteria and possibly small zooplankton which may affect pCd:P ratios. Ultimately, the near-surface $\mathrm{pCd}: \mathrm{P}$ maxima were consistent with increasing $\mathrm{dCd}: \mathrm{PO}_{4}$ ratios with depth at each station and in agreement with previous suggestions of $\mathrm{pCd}$ and $\mathrm{P}$ remineralisation length scales impacting ratios of $\mathrm{dCd}$ to $\mathrm{PO}_{4}$ in surface and subsurface waters (Quay et al., 2015; Bourne et al., 2018).

\section{Physical Resupply of dCd Through Upwelling and Deep Winter Mixing}

Considering biological uptake as the only control of surface $\mathrm{dCd}$ (and $\mathrm{PO}_{4}$ ), and the strong preferential uptake of $\mathrm{dCd}$ (relative to $\mathrm{PO}_{4}$ ) in the $\mathrm{PFZ}$ and $\mathrm{AAZ}$ compared to the north, we would expect surface dCd to remain low throughout the southern section of the transect. However, the mean SML dCd concentration in the PFZ and AAZ was between 318 and $714 \mathrm{pmol} \mathrm{kg}^{-1}$ and significantly higher compared to stations to the north (Figure 2A). The strong surface dCd gradient was likely the result of the upwelling of underlying water masses, primarily UCDW, which supply dCd enriched waters to the surface layer. Upwelling of UCDW occurs in the AAZ, where UCDW was sampled between $300-600 \mathrm{~m}$. This water is then transported northwards into the upper water column of the lower latitudes (Orsi et al., 1995). Importantly, UCDW carried a high mean dCd: $\mathrm{PO}_{4}$ spot ratio of $367 \pm 70 \mu \mathrm{mol} \mathrm{mol}{ }^{-1}$ (Figure 7B), similar to the previous summer spot ratios $\left(365 \mu \mathrm{mol} \mathrm{mol}^{-1}\right.$; Baars et al., 2014). The dCd: $\mathrm{PO}_{4}$ spot ratios in UCDW increased southwards and reached a maximum of $\sim 500 \mu \mathrm{mol} \mathrm{mol}^{-1}$ below the SML in the AAZ. The source of the 'excess' dCd relative to $\mathrm{PO}_{4}$ was predominantly the remineralisation of particles with high pCd:P (Figure 7A) which was set during biological uptake within the SML, as observed elsewhere in the Southern Ocean (Abouchami et al., 2014; Baars et al., 2014; Middag et al., 2018; Sieber et al., 2019).

In addition to the strong latitudinal trends in $\mathrm{dCd}: \mathrm{PO}_{4}$ spot ratios, we observed a significant increase with depth (Figure 7B). The high dCd: $\mathrm{PO}_{4}$ spot ratios found beneath the summer mixed layer support the notion of a physical resupply of excess dCd (i.e., preferential resupply of $\mathrm{dCd}$ relative to $\mathrm{PO}_{4}$ ) to the SML through deep winter mixing. While our sampling took place before the period of maximum nutrient recharge, between August and November (Johnson et al., 2017), the early winter MLDs in the SAZ were similar to the maximum values $(\sim 200 \mathrm{~m})$ expected in west Indian sector (Sallée et al., 2010) suggesting deep winter mixing and nutrient recharge was ongoing. Deep winter mixing is an important nutrient resupply mechanism in the Southern Ocean as shown previously for Fe (Tagliabue et al., 2014; Mtshali et al., 2019) and other trace metals (Cloete et al., 2019). Here, deeper mixing during the winter months allows access to subsurface waters with $\mathrm{dCd}$ enrichments relative to $\mathrm{PO}_{4}$ (i.e., higher $\mathrm{dCd}: \mathrm{PO}_{4}$ spot ratios) found below the depleted summer mixed layer, potentially resupplying dissolved nutrients which may aid and sustain local phytoplankton production through the spring and summer months. For example, in the STZ and SAZ, dCd:PO $\mathrm{PO}_{4}$ increased by two-threefold from 49 to
$85 \mu \mathrm{mol} \mathrm{mol}^{-1}$ at the depth of the average summer mixed layer in this region (60-80 m; WOCE Global Data Resource, 2018), to values of $162-178 \mu \mathrm{mol} \mathrm{mol}{ }^{-1}$ at the base of the winter mixed layer ( $\sim 200 \mathrm{~m}$; Figure 7B). Winter deep mixing may be of particular importance in the STZ and SAZ where summer surface dCd can be depleted to $<10 \mathrm{pmol} \mathrm{kg}^{-1}$ (Boye et al., 2012).

\section{dCd in Intermediate and Deep Waters and the Importance of Water Mass Mixing}

While $\mathrm{dCd}$ and $\mathrm{PO}_{4}$ are well correlated, our data show a change in the steepness of the regression between $\mathrm{dCd}$ and $\mathrm{PO}_{4}\left(\mathrm{dCd} / \mathrm{PO}_{4}\right)$ at $\mathrm{PO}_{4}>1.0 \mu \mathrm{mol} \mathrm{kg}{ }^{-1}$ (Figure 8), a feature commonly referred to as the 'kink', and which is evident in the global $\mathrm{dCd} / \mathrm{dPO}_{4}$ relationship (Middag et al., 2018), derived from the GEOTRACES 2017 Intermediate Data Product (Schlitzer et al., 2018). The samples with low $\mathrm{dCd}$ and $\mathrm{PO}_{4}$ represent surface waters from the STZ and SAZ and plot on a relatively shallow linear slope (61 $\pm 9 \mu \mathrm{mol} \mathrm{mol}^{-1}$ ) with a slightly negative intercept indicating a slight preferential uptake of $\mathrm{Cd}$ relative to $\mathrm{PO}_{4}$. Our winter slope value is higher compared to summer STZ and SAZ surface waters (31 $\pm 6 \mu \mathrm{mol} \mathrm{mol}{ }^{-1}$; Boye et al., 2012; Baars et al., 2014) likely reflecting preferential $\mathrm{dCd}$ recharge (relative to $\mathrm{PO}_{4}$ ) as a result of deep winter mixing as discussed previously (see section "Physical Resupply of dCd Through Upwelling and Deep Winter Mixing"). The higher $\mathrm{dCd} / \mathrm{PO}_{4}$ signatures of intermediate and deep water masses are collectively represented by the steep linear slope (Frew and Hunter, 1992). We calculate a $\mathrm{dCd} / \mathrm{PO}_{4}$ slope value of $453 \pm 68 \mu \mathrm{mol} \mathrm{mol}^{-1}(n=73)$ for these waters which is similar to slopes observed in previous Southern Ocean winter measurements (444 $\pm 11 \mu \mathrm{mol} \mathrm{mol}^{-1}$; Ellwood, 2008), and lower than slope values in the Atlantic sector of the Southern Ocean (590 $\pm 12 \mu \mathrm{mol} \mathrm{mol}{ }^{-1}$; Boye et al., 2012; Baars et al., 2014). The high slope values and negative intercepts in our winter data suggest a combination of preferential uptake (and subsurface regeneration) of $\mathrm{dCd}$ relative to $\mathrm{PO}_{4}$ but also strong upwelling of dCd enriched water masses in the AAZ (Baars et al., 2014). Furthermore, we identify that in fact multiple linear regressions describe data from the steep slope (Figure 8) as shown previously in the Atlantic (Middag et al., 2018). Each slope represents a different water mass and it is assumed that mixing between water masses with different origins and hence, different preformed nutrient components, results in a new regression where the slope value falls between the slope values of the water mass endmembers being mixed. For example, NADW has a $\mathrm{dCd} / \mathrm{dPO}_{4}$ slope value of $250 \mu \mathrm{mol} \mathrm{mol}^{-1}$ at its source in the high latitude North Atlantic (Bruland and Franks, 1983) compared to a slope value of $311 \pm 13 \mu \mathrm{mol} \mathrm{mol}{ }^{-1}(n=8)$ measured here. As NADW flows southward across the equator, the increase in slope value arises from mixing with northward flowing AAIW (341 $\left.\pm 31 \mu \mathrm{mol} \mathrm{mol}{ }^{-1} ; n=30\right)$ at intermediate depths and at deeper depths with CDW (344 $\left.\pm 77 \mu \mathrm{mol} \mathrm{mol}^{-1} ; n=38\right)$ and $\operatorname{AABW}\left(2934 \pm 44 \mu \mathrm{mol} \mathrm{mol}{ }^{-1} ; n=4\right)$. These Antarctic derived water masses have higher $\mathrm{dCd} / \mathrm{dPO}_{4}$ slope values such that the slope for NADW observed here lies between its source waters and the waters it interacted with. Our observations clearly 


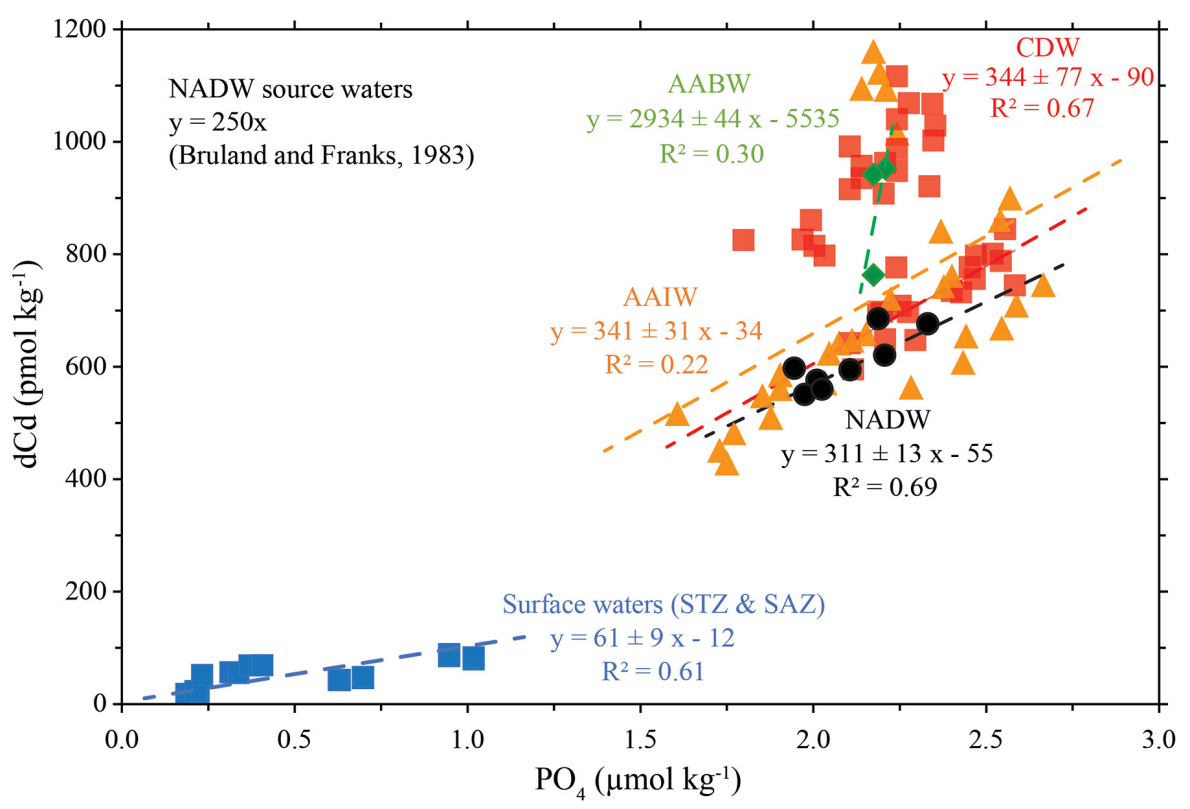

FIGURE 8 | Plot of $\mathrm{dCd} / \mathrm{dPO}_{4}$ ratios, defined as the slope of regression between $\mathrm{dCd}$ and $\mathrm{PO}_{4}$, for various water masses.

show the strong influence of water mass end-member mixing on deep dCd distributions in this region and is consistent with data from the Atlantic and Pacific sectors of the Southern Ocean (Baars et al., 2014, Sieber et al., 2019; Janssen et al., 2020).

\section{CONCLUSION}

This study presents the first winter measurements of dissolved cadmium $(\mathrm{dCd})$ and particulate cadmium $(\mathrm{pCd})$ along the $30^{\circ} \mathrm{E}$ longitude in the Indian Sector of the Southern Ocean and provides a unique opportunity to investigate $\mathrm{Cd}$ cycling during a period characterized by contrasting upper water column dynamics compared to summer. Our data suggest that biological uptake of trace metals is an important factor to consider during the winter season despite unfavorable growth conditions for phytoplankton. At all stations, dCd was lowest in the SML and increased with depth. Conversely, pCd was highest in the SML, but not necessarily in the shallowest euphotic zone sample, and decreased rapidly with depth. The vertical behaviors of both $\mathrm{dCd}$ and $\mathrm{pCd}$ are consistent with biological uptake in surface waters and remineralisation in the subsurface. Concentrations of $\mathrm{dCd}$ (relative to $\mathrm{PO}_{4}$ ) near the surface were higher than comparable summer measurements, most evident in the high latitude AAZ, likely reflecting a combination of weaker biological uptake and preferential dCd recharge through deep winter mixing. We observed distinct regional trends in $\mathrm{Cd}$ uptake and remineralisation reflecting a combination of changes in phytoplankton community composition and the availability of both dCd other trace metals such as Fe, Zn and Mn. Our data also provided evidence for differential remineralisation rates of $\mathrm{pCd}$ vs. $\mathrm{P}$ with depth at each station with implications for ratios of $\mathrm{dCd}$ to $\mathrm{PO}_{4}$ in the upper water column. The combined effect of diatom uptake and regeneration characteristics and the upwelling of water masses in the PFZ and AAZ resulted in a strong southward increase in surface dCd. In the intermediate and deep waters, where $\mathrm{dCd}$ dominated the total Cd inventory, there were distinct water mass-dependent relationships between linear regressions of $\mathrm{dCd}$ versus $\mathrm{dPO}_{4}$ which suggested that dCd distributions are largely the result of mixing between northward traveling waters of Antarctic origin with high $\mathrm{dCd} / \mathrm{dPO}_{4}$ signatures and southward traveling NADW with an inherently low $\mathrm{dCd} / \mathrm{dPO}_{4}$ signature.

\section{DATA AVAILABILITY STATEMENT}

The raw data supporting the conclusions of this article will be made available by the authors, without undue reservation, to any qualified researcher.

\section{AUTHOR CONTRIBUTIONS}

RC, JL, NH, and TM collected field samples. RC and JL analyzed for dissolved $\mathrm{Cd}$. $\mathrm{NH}$ and $\mathrm{HP}$ analyzed for particulate $\mathrm{Cd}$. RC wrote the manuscript with contributions from SF and AR. AR provided funds for the study. All authors commented on previous drafts of the manuscript, contributed to the final submission draft and approved the submitted version.

\section{FUNDING}

RC was supported through the National Research Foundation (NRF) Innovation Ph.D. studentship. This research was supported by NRF grants (UID\# 93069, 105826, and 110715) to AR. SF acknowledges funding from NRF (UID 111210 and 110731). 


\section{ACKNOWLEDGMENTS}

We would like to thank the South African National Antarctic Programme (SANAP) as well as Captain Knowledge Bengu and the crew of the R/V SA Agulhas II for their professionalism and support during the winter 2017 voyage. We acknowledge Chief Scientist Marcello Vichi and all the participants involved in the expedition. We are grateful to the "Iron" team for their help in collecting trace-clean seawater samples. We thank the two reviewers for their efforts which resulted in an improved manuscript. We would like to thank Gideon

\section{REFERENCES}

Abouchami, W., Galer, S. J. G., De Baar, H. J. W., Middag, R., Vance, D., Zhao, Y., et al. (2014). Biogeochemical cycling of cadmium isotopes in the Southern Ocean along the Zero Meridian. Geochim. Cosmochim. Acta 127, 348-367. doi: 10.1016/j.gca.2013.10.022

Anilkumar, N., Luis, A. J., Somayajulu, Y. K., Ramesh Babu, V., Dash, M. K., Pednekar, S. M., et al. (2006). Fronts, water masses and heat content variability in the Western Indian sector of the Southern Ocean during austral summer 2004. J. Mar. Syst. 63, 20-34. doi: 10.1016/j.jmarsys.2006.04.009

Baars, O., Abouchami, W., Galer, S., Boye, M., and Croot, P. (2014). Dissolved cadmium in the Southern Ocean: Distribution, speciation, and relation to phosphate. Limnol. Ocean. 59, 385-399. doi: 10.4319/lo.2014.59.2.0385

Baars, O., and Croot, P. L. (2011). The speciation of dissolved zinc in the Atlantic sector of the Southern Ocean. Deep. Res. Part II Top. Stud. Oceanogr. 58, 2720-2732. doi: 10.1016/j.dsr2.2011.02.003

Becquevort, S., Menon, P., and Lancelot, C. (2000). Differences of the protozoan biomass and grazing during spring and summer in the Indian sector of the Southern Ocean. Polar Biol. 23, 309-320. doi: 10.1007/s00300005 0450

Belkin, I. M., and Gordon, A. L. (1996). Southern Ocean fronts from the Greewich meridian to Tasmania. J. Geophys. Res. 101, 3675-3696. doi: 10.1029/95JC02750

Bourne, H. L., Bishop, J. K. B., Lam, P. J., and Ohnemus, D. C. (2018). Global Spatial and Temporal Variation of Cd:P in Euphotic Zone Particulates. Global Biogeochem. Cycles 32, 1123-1141. doi: 10.1029/2017GB005842

Boye, M., Wake, B. D., Lopez Garcia, P., Bown, J., Baker, A. R., and Achterberg, E. P. (2012). Distributions of dissolved trace metals (Cd, Cu, Mn, Pb, Ag) in the southeastern Atlantic and the Southern Ocean. Biogeosciences 9, 3231-3246. doi: 10.5194/bg-9-3231-2012

Boyle, E. A., Sclater, F., and Edmond, J. M. (1976). On the marine geochemistry of cadmium. Nature 263, 42-44. doi: 10.1038/263042a0

Broecker, W. S. (1991). The Great Ocean Conveyor. Oceanography 4, 79-89. doi: 10.5670/oceanog.1991.07https

Bruland, K. W., and Franks, R. P. (1983). Mn, Ni, Cu, Zn and Cd in the Western North Atlantic. Trace Met. Sea Water. 9, 395-396. doi: 10.1007/978-1-47576864-0_23

Bruland, K. W., Knauer, G. A., and Martin, J. H. (1978). Cadmium in Northeast Pacific Waters. Limnol. Oceanogr. 23, 618-625. doi: 10.4319/lo.1978.23.4.0618

Butler, E. C. V., O’Sullivan, J. E., Watson, R. J., Bowie, A. R., Remenyi, T. A., and Lannuzel, D. (2013). Trace metals $\mathrm{Cd}, \mathrm{Co}, \mathrm{Cu}, \mathrm{Ni}$, and $\mathrm{Zn}$ in waters of the subantarctic and Polar Frontal Zones south of Tasmania during the "SAZ-Sense" project. Mar. Chem. 148, 63-76. doi: 10.1016/j.marchem.2012.1 0.005

Cloete, R., Loock, J. C., Mtshali, T., Fietz, S., and Roychoudhury, A. N. (2019). Winter and summer distributions of Copper, Zinc and Nickel along the International GEOTRACES Section GIPY05: Insights into deep winter mixing. Chem. Geol. 511, 342-357. doi: 10.1016/j.chemgeo.2018. 10.023

Conway, T. M., and John, S. G. (2015). Biogeochemical cycling of cadmium isotopes along a high-resolution section through the North Atlantic Ocean. Geochim. Cosmochim. Acta 148, 269-283. doi: 10.1016/j.gca.2014. 09.032
Henderson, Eric Achterberg, Angela Milne, Maeve Lohan, Andrew Bowie, Yoshiki Sohrin, and Michael Ellwood for allowing permission to use data that are not published outside of the IDP2017.

\section{SUPPLEMENTARY MATERIAL}

The Supplementary Material for this article can be found online at: https://www.frontiersin.org/articles/10.3389/fmars. 2021.656321/full\#supplementary-material

Croot, P. L., Andersson, K., Öztürk, M., and Turner, D. R. (2004). The distribution and speciation of iron along $6^{\circ} \mathrm{E}$ in the Southern Ocean. Deep. Res. Part II Top. Stud. Oceanogr. 51, 2857-2879. doi: 10.1016/j.dsr2.2003.10.012

Cullen, J. T. (2006). On the nonlinear relationship between dissolved cadmium and phosphate in the modern global ocean : Could chronic iron limitation of phytoplankton growth cause the kink ? Limnol. Oceanogr. 51, 1369-1380. doi: $10.4319 /$ lo.2006.51.3.1369

Cullen, J. T., and Sherrell, R. M. (2005). Effects of dissolved carbon dioxide, zinc, and manganese on the cadmium to phosphorus ratio in natural phytoplankton assemblages. Limnol. Oceanogr. 50, 1193-1204. doi: 10.4319/lo.2005.50.4.1193

Cullen, J. T., Chase, Z., Coale, K. H., Fitzwater, S. E., and Sherrell, R. M. (2003). Effect of iron limitation on the cadmium to phosphorous ratio of natural phytoplankton assemblages from the Southern Ocean. Limnol. Oceanogr. 48, 1079-1087. doi: 10.4319/lo.2003.48.3.1079

Cullen, J. T., Lane, T. W., Morel, F. M. M., and Sherrell, R. M. (1999). Modulation of cadmium uptake in phytoplankton by seawater $\mathrm{CO} 2$ concentration. Nature 402, 165-167. doi: 10.1038/46007

Cutter, G., Casciotti, K., Croot, P., Geibert, W., Heimbürger, L.-E., Lohan, M., et al. (2017). Sampling and Sample-handling Protocols for GEOTRACES Cruises. Version 3. Toulouse: GEOTRACES International Project Office.

de Jong, E., Vichi, M., Mehlmann, C. B., Eayrs, C., De Kock, W., Moldenhauer, M., et al. (2018). Sea Ice conditions within the Antarctic Marginal Ice Zone in winter 2017, onboard the SA Agulhas II, in: PANGAEA. Cape Town: University of Cape Town.

Dong, S., Sprintall, J., Gille, S. T., and Talley, L. (2008). Southern ocean mixedlayer depth from Argo float profiles. J. Geophys. Res. Ocean. 113, 1-12. doi: 10.1029/2006JC004051

Duce, R. A., Liss, P. S., Merrill, J. T., Atlas, E. L., Hicks, B. B., Millertl, J. M., et al. (1991). The atmospheric input of trace species to the world ocean. Global Biogeochem. Cycles 5, 193-259. doi: 10.1029/91gb01778

Elderfield, H., and Rickaby, R. E. M. (2000). Oceanic Cd/P ratio and nutrient utilization in the glacial Southern Ocean. Nature 405, 305-310. doi: 10.1038/ 35012507

Ellwood, M. J. (2004). Zinc and cadmium speciation in subantarctic waters east of New Zealand. Mar. Chem. 87, 37-58. doi: 10.1016/j.marchem.2004.01.005

Ellwood, M. J. (2008). Wintertime trace metal ( $\mathrm{Zn}, \mathrm{Cu}, \mathrm{Ni}, \mathrm{Cd}, \mathrm{Pb}$ and $\mathrm{Co}$ ) and nutrient distributions in the Subantarctic Zone between $40-52^{\circ} \mathrm{S} ; 155-160^{\circ} \mathrm{E}$. Mar. Chem. 112, 107-117. doi: 10.1016/j.marchem.2008.07.008

Finkel, Z. V., Quigg, A. S., Chiampi, R. K., Schofield, O. E., and Falkowski, P. G. (2007). Phylogenetic diversity in cadmium: Phosphorus ratio regulation by marine phytoplankton. Limnol. Oceanogr. 52, 1131-1138. doi: 10.4319/lo.2007. 52.3.1131

Frew, R. D., and Hunter, K. A. (1992). Influence of Southern Ocean waters on the cadmium-phosphate properties of the global ocean. Nature 360, 144-146. doi: $10.1038 / 360144 \mathrm{a} 0$

Grasshoff, K. (1983). “Automated chemical analysis," in Methods of Seawater Analysis, eds K. Grasshoff, M. Ernhardt, and K. Kremling (New York, NY: Verlag Chemie Weinhein), 263-289. doi: 10.1002/9783527613984

Hayes, C. T., Black, E. E., Anderson, R. F., Baskaran, M., Buesseler, K. O., Charette, M. A., et al. (2018). Flux of Particulate Elements in the North Atlantic Ocean Constrained by Multiple Radionuclides. Glob. Biogeochem. Cycles 32, 1738-1758. doi: 10.1029/2018GB005994 
Ho, T.-Y., Quigg, A., Finkel, Z. V., Milligan, A. J., Wyman, K., Falkowski, P. G., et al. (2003). The elemental composition of some marine phytoplankton. J. Phycol. 39, 1145-1159. doi: 10.1111/j.0022-3646.2003.03-090.x

Hölemann, J. A., Schirmacher, M., and Prange, A. (1999). Dissolved and Particulate Major and Trace Elements in Newly Formed Ice from the Laptev Sea (Transdrift III, October 1995), Land-Ocean Systems in the Siberian Arctic. Berlin: SpringerVerlag, doi: 10.1007/978-3-642-60134-7_11

Horner, T. J., Lee, R. B. Y., Henderson, G. M., and Rickaby, R. E. M. (2013). Nonspecific uptake and homeostasis drive the oceanic cadmium cycle. Proc. Natl. Acad. Sci. U S A. 110, 2500-2505. doi: 10.1073/pnas.1213857110//DCSupplemental.www.pnas.org/cgi//10.1073/pnas.12138 57110

Janssen, D. J., Abouchami, W., Galer, S. J. G., and Cullen, J. T. (2017). Finescale spatial and interannual cadmium isotope variability in the subarctic northeast Pacific. Earth Planet. Sci. Lett. 472, 241-252. doi: 10.1016/j.eps1.2017.0 4.048

Janssen, D. J., Conway, T. M., John, S. G., Christian, J. R., Kramer, D. I., Pedersen, T. F., et al. (2014). Undocumented water column sink for cadmium in open ocean oxygen-deficient zones. Proc. Natl. Acad. Sci. U S A. 111, 6888-6893. doi: 10.1073/pnas.1402388111

Janssen, D. J., Sieber, M., Ellwood, M. J., Conway, T. M., Barrett, P. M., Chen, X., et al. (2020). Trace metal and nutrient dynamics across broad biogeochemical gradients in the Indian and Pacific sectors of the Southern Ocean. Mar. Chem. 221:103773. doi: 10.1016/j.marchem.2020.103773

John, S. G., Helgoe, J., and Townsend, E. (2017). Biogeochemical cycling of Zn and $\mathrm{Cd}$ and their stable isotopes in the Eastern Tropical South Pacific. Mar. Chem. 201, 256-262. doi: 10.1016/j.marchem.2017.06.001

Johnson, K. S., Plant, J. N., Dunne, J. P., Talley, L. D., and Sarmiento, J. L. (2017). Annual nitrate drawdown observed by SOCCOM profiling floats and the relationship to annual net community production. J. Geophys. Res. Ocean. 122, 6668-6683. doi: 10.1002/2017JC012839

Kuss, J., and Kremling, K. (1999). Spatial variability of particle associated trace elements in near-surface waters of the North Atlantic $\left(30{ }^{\circ} \mathrm{N} / 60{ }^{\circ} \mathrm{W}\right.$ to 60 $\left.{ }^{\circ} \mathrm{N} / 2{ }^{\circ} \mathrm{W}\right)$, derived by large volume sampling. Mar. Chem. 68, 71-86. doi: 10.1016/S0304-4203(99)00066-3

Lam, P. J., and Marchal, O. (2015). Insights into Particle Cycling from Thorium and Particle Data. Ann. Rev. Mar. Sci. 7, 159-184. doi: 10.1146/annurev-marine010814-015623

Lambelet, M., Rehkämper, M., van de Flierdt, T., Xue, Z., Kreissig, K., Coles, B., et al. (2013). Isotopic analysis of $\mathrm{Cd}$ in the mixing zone of Siberian rivers with the Arctic Ocean-New constraints on marine Cd cycling and the isotope composition of riverine Cd. Earth Planet. Sci. Lett. 361, 64-73. doi: 10.1016/j. epsl.2012.11.034

Lane, E. S., Jang, K., Cullen, J. T., and Maldonado, M. T. (2008). The interaction between inorganic iron and cadmium uptake in the marine diatom Thalassiosira oceanica. Limnol. Oceanogr. 53, 1784-1789. doi: 10.4319/lo.2008. 53.5.1784

Lane, E. S., Semeniuk, D. M., Strzepek, R. F., Cullen, J. T., and Maldonado, M. T. (2009). Effects of iron limitation on intracellular cadmium of cultured phytoplankton: Implications for surface dissolved cadmium to phosphate ratios. Mar. Chem. 115, 155-162. doi: 10.1016/j.marchem.2009.0 7.008

Lane, T. W., and Morel, F. M. M. (2000). A biological function for cadmium in marine diatoms. Proc. Natl. Acad. Sci. U S A. 97, 4627-4631. doi: 10.1073/pnas. 090091397

Lane, T. W., Saito, M. A., George, G. N., Prince, R. C., Pickering, I. J., and Morel, F. M. M. (2005). A cadmium enzyme from a marine diatom. Nature 435, 42-42. doi: $10.1038 / 435042 \mathrm{a}$

Lee, J. G., and Morel, F. M. M. (1995). Replacement of zinc by cadmium in marine phytoplankton. Mar. Ecol. Prog. Ser. 127, 305-309. doi: 10.3354/meps12 7305

Lee, J. M., Heller, M. I., and Lam, P. J. (2018). Size distribution of particulate trace elements in the U.S. GEOTRACES Eastern Pacific Zonal Transect (GP16). Mar. Chem. 201, 108-123. doi: 10.1016/j.marchem.2017.09.006

Middag, R., van Heuven, S. M. A. C., Bruland, K. W., and de Baar, H. J. W. (2018). The relationship between cadmium and phosphate in the Atlantic
Ocean unravelled. Earth Planet. Sci. Lett. 492, 79-88. doi: 10.1016/j.epsl.2018.0 3.046

Minami, T., Konagaya, W., Zheng, L., Takano, S., Sasaki, M., Murata, R., et al. (2015). An off-line automated preconcentration system with ethylenediaminetriacetate chelating resin for the determination of trace metals in seawater by high-resolution inductively coupled plasma mass spectrometry. Anal. Chim. Acta 854, 183-190. doi: 10.1016/j.aca.2014.1 1.016

Mtshali, T. N., Horsten, N. R., Thomalla, S. J., Ryan-Keogh, T. J., Nicholson, S. A., Roychoudhury, A. N., et al. (2019). Seasonal depletion of the dissolved iron reservoirs in the sub-Antarctic zone of the Southern Atlantic Ocean. Geophys. Res. Lett. 2019:2018GL081355. doi: 10.1029/2018GL08 1355

Orsi, A. H., Whitworth, T., and Nowlin, W. D. (1995). On the meridional extent and fronts of the Antarctic Circumpolar Current. Deep. Res. Part I 42, 641-673. doi: 10.1016/0967-0637(95)00021-W

Planquette, H., and Sherrell, R. M. (2012). Sampling for particulate trace element determination using water sampling bottles: methodology and comparison to in situ pumps. Limnol. Oceanogr. Methods 10, 367-388. doi: 10.4319/lom.2012. 10.367

Pollard, R. T., Lucas, M. I., and Read, J. F. (2002). Physical controls on biogeochemical zonation in the Southern Ocean. Deep. Res. Part II Top. Stud. Oceanogr. 49, 3289-3305. doi: 10.1016/S0967-0645(02)00084-X

Price, N. M., and Morel, F. M. M. (1990). Cadmium and Cobalt substitution for $\mathrm{Zn}$ in a marine diatom. Nature 344, 658-660. doi: 10.1038/3446 $58 \mathrm{a} 0$

Quay, P., Cullen, J., Landing, W., and Morton, P. (2015). Processes controlling the distributions of $\mathrm{Cd}$ and PO4 in the ocean. Global Biogeochem. Cycles 29, 830-841. doi: 10.1002/2014GB004998

Rembauville, M., Blain, S., Caparros, J., and Salter, I. (2016). Particulate matter stoichiometry driven by microplankton community structure in summer in the Indian sector of the Southern Ocean. Limnol. Oceanogr. 61, 1301-1321. doi: 10.1002/lno.10291

Sallée, J. B., Speer, K., Rintoul, S., and Wijffels, S. (2010). Southern Ocean Thermocline Ventilation. J. Phys. Oceanogr. 40, 509-529. doi: 10.1175/ 2009JPO4291.1

Sarmiento, J. L., Gruber, N., Brzezinski, M. A., and Dunne, J. P. (2004). High-latitude controls of thermocline nutrients and low latitude biological productivity. Nature 427, 56-60. doi: 10.1038/nature10605

Schlitzer, R. (2020). Ocean Data View. Cambridge: Cambridge University Press, doi: 10.1017/CBO9781107415324.004

Schlitzer, R., Anderson, R. F., Dodas, E. M., Lohan, M., Geibert, W., Tagliabue, A., et al. (2018). The GEOTRACES Intermediate Data Product 2017. Chem. Geol. 493, 210-223. doi: 10.1016/j.chemgeo.2018.05.040

Sieber, M., Conway, T. M., Souza, G. F., De, Hassler, C. S., Ellwood, M. J., et al. (2019). High-resolution Cd isotope systematics in multiple zones of the Southern Ocean from the Antarctic Circumnavigation Expedition. Earth Planet. Sci. Lett. 527:115799. doi: 10.1016/j.epsl.2019.11 5799

Sunda, W. G., and Huntsman, S. A. (2000). Effect of Zn, Mn, and Fe on Cd accumulation in phytoplankton: Implications for oceanic Cd cycling. Limnol. Oceanogr. 45, 1501-1516. doi: 10.4319/lo.2000.45.7.1501

Swart, S., Thomalla, S. J., and Monteiro, P. M. S. (2015). The seasonal cycle of mixed layer dynamics and phytoplankton biomass in the Sub-Antarctic Zone: A highresolution glider experiment. J. Mar. Syst. 147, 103-115. doi: 10.1016/j.jmarsys. 2014.06.002

Tagliabue, A., Sallée, J. B., Bowie, A. R., Lévy, M., Swart, S., and Boyd, P. W. (2014). Surface-water iron supplies in the Southern Ocean sustained by deep winter mixing. Nat. Geosci. 7, 314-320. doi: 10.1038/ngeo2101

Thi Dieu Vu, H., and Sohrin, Y. (2013). Diverse stoichiometry of dissolved trace metals in the Indian Ocean. Sci. Rep. 3, 1-5. doi: 10.1038/srep01745

Turekian, K. K. (1977). The fate of metals in the oceans. Geochim. Cosmochim. Acta 41, 1139-1144. doi: 10.1016/0016-7037(77)90109-0

Twining, B. S., and Baines, S. B. (2013). The trace metal composition of marine phytoplankton. Ann. Rev. Mar. Sci. 5, 191-215. doi: 10.1146/annurev-marine121211-172322 
Weir, I., Fawcett, S., Smith, S., Walker, D., Bornman, T., and Fietz, S. (2020). Winter biogenic silica and diatom distributions in the Indian sector of the Southern Ocean. Deep Sea Res. Part I Oceanogr. Res. Pap. 166:103421. doi: 10.1016/j.dsr.2020.103421

WOCE Global Data Resource (2018). NODC Standard Product: World Ocean Circulation Experiment (WOCE) Global Data Resource (GDR), versions 1-3, on $C D-R O M$ and DVD. Washington, D.C: NOAA.

Xie, R. C., Galer, S. J. G., Abouchami, W., and Frank, M. (2018). Limited impact of eolian and riverine sources on the biogeochemical cycling of $\mathrm{Cd}$ in the tropical Atlantic. Chem. Geol. 511, 371-379. doi: 10.1016/j.chemgeo.2018. 10.018

Xie, R. C., Galer, S. J. G., Abouchami, W., Rijkenberg, M. J. A., De Jong, J., De Baar, H. J. W., et al. (2015). The cadmium-phosphate relationship in the western South Atlantic - The importance of mode and intermediate waters on the global systematics. Mar. Chem. 177, 110-123. doi: 10.1016/j.marchem.2015.0 6.011

Xu, Y., Tang, D., Shaked, Y., and Morel, F. M. M. (2007). Zinc, cadmium, and cobalt interreplacement and relative use efficiencies in the coccolithophore Emiliania huxleyi. Limnol. Oceanogr. 52, 2294-2305. doi: 10.2307/450 2377
Conflict of Interest: The authors declare that the research was conducted in the absence of any commercial or financial relationships that could be construed as a potential conflict of interest.

The reviewer GD declared a past co-authorship with one of the authors HP to the handling editor.

Publisher's Note: All claims expressed in this article are solely those of the authors and do not necessarily represent those of their affiliated organizations, or those of the publisher, the editors and the reviewers. Any product that may be evaluated in this article, or claim that may be made by its manufacturer, is not guaranteed or endorsed by the publisher.

Copyright (c) 2021 Cloete, Loock, van Horsten, Fietz, Mtshali, Planquette and Roychoudhury. This is an open-access article distributed under the terms of the Creative Commons Attribution License (CC BY). The use, distribution or reproduction in other forums is permitted, provided the original author(s) and the copyright owner(s) are credited and that the original publication in this journal is cited, in accordance with accepted academic practice. No use, distribution or reproduction is permitted which does not comply with these terms. 